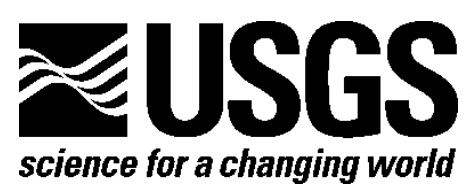

Prepared in cooperation with the Bureau of Ocean Energy Management

\title{
Oregon OCS Seafloor Mapping: Selected Lease Blocks Relevant to Renewable Energy
}

BOEM Intra-agency Agreement M13PG00037

By Guy R. Cochrane, Lenaïg G. Hemery, and Sarah K. Henkel

Open-File Report 2017-1045

Bureau of Ocean Energy Management OCS Study BOEM 2017-018

U.S. Department of the Interior

U.S. Geological Survey

Bureau of Ocean Energy Management 


\title{
U.S. Department of the Interior RYAN K. ZINKE, Secretary
}

\author{
U.S. Geological Survey \\ William H. Werkheiser, Acting Director
}

U.S. Geological Survey, Reston, Virginia: 2017

For more information on the USGS-the Federal source for science about the Earth, its natural and living resources, natural hazards, and the environment-visit https://www.usgs.gov/ or call 1-888-ASK-USGS (1-888-275-8747).

For an overview of USGS information products, including maps, imagery, and publications, visit https://www.usgs.gov/pubprod/.

Any use of trade, firm, or product names is for descriptive purposes only and does not imply endorsement by the U.S. Government.

Although this information product, for the most part, is in the public domain, it also may contain copyrighted materials as noted in the text. Permission to reproduce copyrighted items must be secured from the copyright owner.

\section{Suggested citation:}

Cochrane, G.R., Hemery, L.G., and Henkel, S.K., 2017, Oregon OCS seafloor mapping: Selected lease blocks relevant to renewable energy: U.S. Geological Survey Open-File Report 2017-1045 and Bureau of Ocean Energy Management OCS Study BOEM 2017-018, 51 p., https://doi.org/10.3133/ofr20171045. 


\section{Contents}

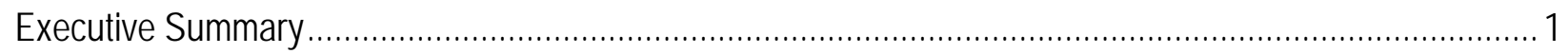

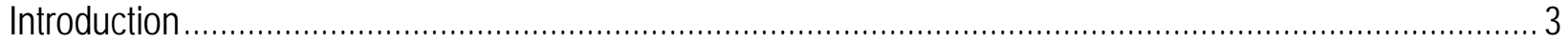

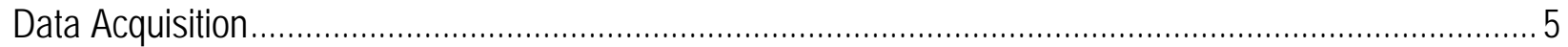

Multibeam Echo Sounder Survey........................................................................................

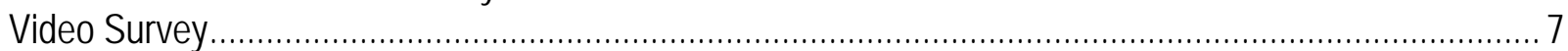

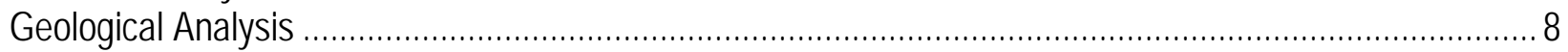

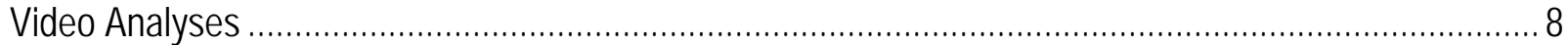

Seafloor Character Classification .............................................................................................. 14

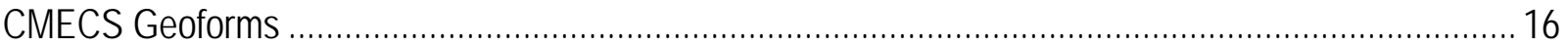

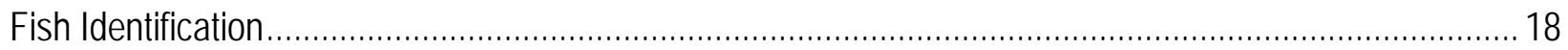

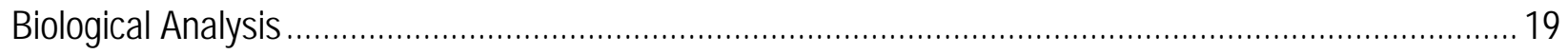

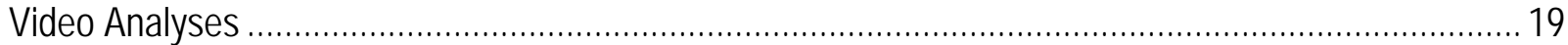

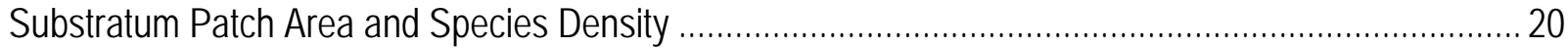

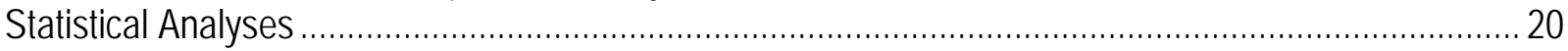

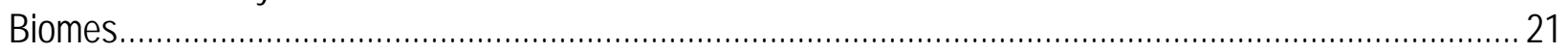

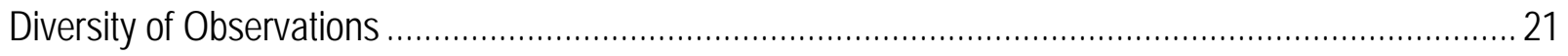

Results of Statistical Analyses on the Invertebrate Data ........................................................... 26

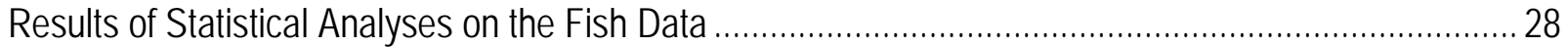

Results of Statistical Analyses on the Combined Fish and Invertebrate Data........................................ 31

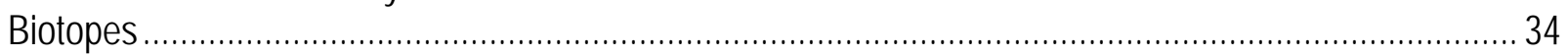

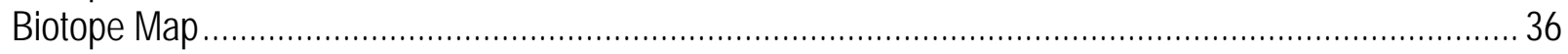

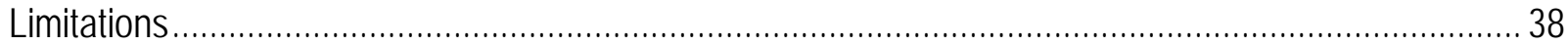

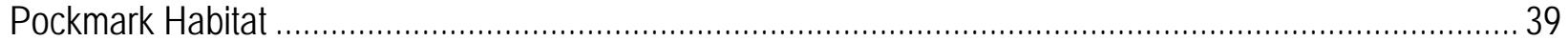

Use of Crinoids as Unique Biogenic Habitat for Three Commercially Fished Taxa................................ 40

Crinoid Species Distribution Modeling...................................................................................... 40

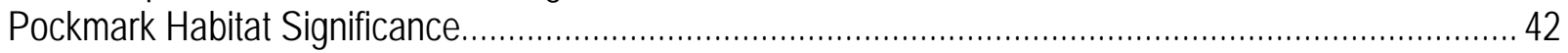

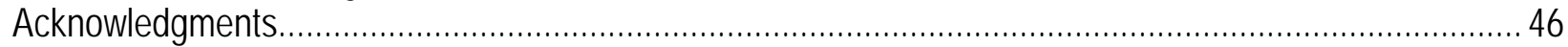

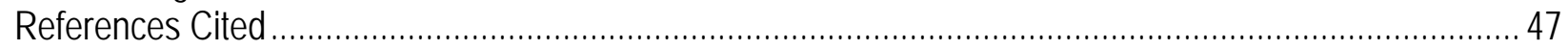

\section{Figures}

1. Map showing the location of the proposed floating wind energy farm.............................................. 3

2. Hillshade image produced from the merged MBES bathymetry digital elevation model. Grid shown is the BOEM lease block grid and block numbers. .................................................................. 6

3. Map showing location and length of the video transects overlain on the hillshade image. Colored dots represent the combinations of primary and secondary substrate observed at points along the video transect. 20 meter isobaths are shown in light grey.................................................................. 8

4. Map showing locations of still images captured from video. Location of still images shown below indicated with large red dots, small red dots show video tracklines. .............................................. 9

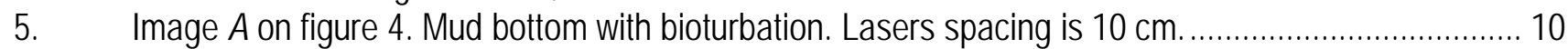

6. Image $B$ on figure 4 . Mud bottom with cobble sized clasts that may be fractured methanogenic carbonates. Lasers spacing is $10 \mathrm{~cm}$................................................................................. 10

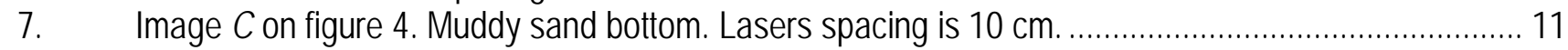

8. Image $D$ on figure 4. Image of angular and partially dissolved methanogenic carbonate clasts in a pockmark. Laser spacing is $10 \mathrm{~cm}$. 
9. Image $E$ on fig. 4. Image of angular and partially dissolved methanogenic carbonate clasts in an area of merged pockmarks. Laser spacing is $10 \mathrm{~cm}$.

10. Image $F$ on fig. 4. Image $D$ on fig. 4. Image of angular and partially dissolved methanogenic carbonate clasts in a pockmark. Laser spacing is $10 \mathrm{~cm}$.

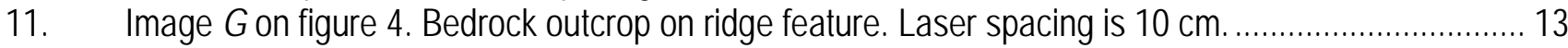

12. Image $H$ on figure 4. Bedrock outcrop on shelf. Laser spacing is $10 \mathrm{~cm}$....................................... 13

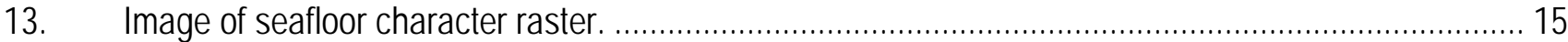

14. Image of CMECS geoforms. Unknown antropogenic feature is a nortwest trending lineation on the east

edge of the study area.

15. Section of east-west oriented multichannel seismic profile across the mapped area just north of the slump feature. A is located above the lineation of pockmarks. Line from B ends at the top of the seafloor multiple reflection. $C$ is located above a gap in the data.

16. Cluster analysis on the invertebrate data, highlighting the seven biomes identified in this study. Symbols indicate depth bin and labels are the dive number and substratum type.

17. Cluster analysis on the fish data, highlighting the fish biomes and their distribution along the depth $(A)$, and the distribution of the invertebrate biomes within these groups $(B)$. Symbols indicate either depth bins or invertebrate biomes, and labels are the dive number and substratum type.

18. Cluster analysis on the combined fish and invertebrate data, highlighting the seven final biomes and their distribution along the depth $(A)$, the distribution of the seven invertebrate biomes within these groups $(B)$, and the distribution of the seven fish biomes within these groups $(C)$. Symbols indicate either depth bins, invertebrate biomes or fish biomes, and labels are the dive number and substratum type.

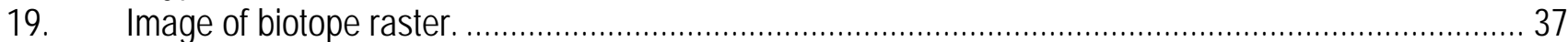

20. Three distance categories of fishes and prawns from their closest crinoid: contact (in red), less than a body length (< BL, in yellow), and more than a body length $(>\mathrm{BL}$, in blue) ................................... 40

21. Distribution of the crinoid Florometra serratissima occurrences (+, left panel) and of the 13 environmental parameters used in this study.

22. Proportions of rockfishes, thornyheads and Pacific spot prawns in contact with crinoids (Contact), at a body length or less away from its nearest crinoid $(\angle \mathrm{BL})$ and at more than a body length away from its nearest crinoid (> BL) within hard flat substrate patches of dives 04,06 and 11.

23. Probability of distribution of the crinoid Florometra serratissima as modeled by Maxent. Isobaths ( 50 , 200 and $500 \mathrm{~m}$ deep) are in white, crinoid occurrences are in red circles.

\section{Tables}

1. Conversion table showing how video observations of primary substrate (more than 50 percent seafloor coverage) and secondary substrate (more than 20 percent seafloor coverage), are grouped into seafloor-character-map Classes I, II, and III for use in seafloor character classification..................... 14

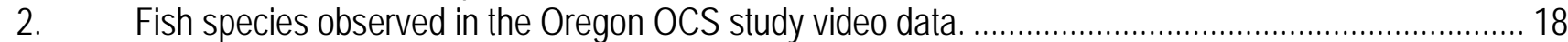

3. Number of segments, total duration and percent of each type of habitat. .......................................... 21

4. Counts and percent of total of the 52,054 sessile and motile organisms and other observations. ........ 22

5. Description of the seven invertebrate biomes, and the dives belonging to each of them..................... 26

6. Percent of similarity within an invertebrate biome (diagonal, in italic) and of dissimilarity in between biomes (lower matrix) from the SIMPER analysis.................................................................. 27

7. Invertebrate assemblage characteristics for each biome based on the SIMPER analysis. ................... 28

8. Description of the fish biomes, and the dives belonging to each of them.......................................... 29 
9. Percent of similarity within a fish biome (diagonal, in italic) and of dissimilarity between biomes (lower matrix) from the SIMPER analysis.

10. Assemblage characteristics for the four major fish biomes based on the SIMPER analysis. ................ 31

11. Description of the final biomes, and the dives belonging to each of them...................................... 31

12. Percent of similarity within a biome (diagonal, in italic) and of dissimilarity in between biomes (lower matrix) from the SIMPER analysis.

13. Assemblage characteristics for each final biome based on the SIMPER analysis. Biome 5 was made of

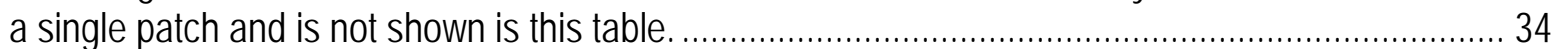

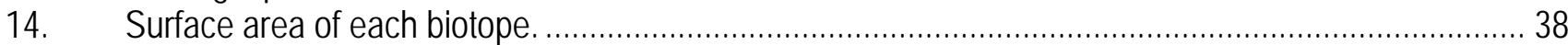

15. Counts of rockfishes, thornyheads and Pacific spot prawns in contact with crinoids (Contact), at a body length or less away from its nearest crinoid $(<\mathrm{BL})$ and at more than a body length away from its nearest crinoid (>BL) within hard flat substrate patches of dives 04,06 and 11.

16. Percent contribution of each thirteen environmental variable to the Maxent model................................ 45 


\title{
Oregon OCS Seafloor Mapping: Selected Lease Blocks Relevant to Renewable Energy
}

\author{
By Guy R. Cochrane ${ }^{1}$, Lenaïg G. Hemery², and Sarah K. Henkel²
}

\section{Executive Summary}

In 2014 the U.S. Geological Survey (USGS) and the Bureau of Ocean Energy Management (BOEM) entered into Intra-agency agreement M13PG00037 to map an area of the Oregon Outer Continental Shelf (OCS) off of Coos Bay, Oregon, under consideration for development of a floating wind energy farm. The BOEM requires seafloor mapping and site characterization studies in order to evaluate the impact of seafloor and sub-seafloor conditions on the installation, operation, and structural integrity of proposed renewable energy projects, as well as to assess the potential effects of construction and operations on archaeological resources. The mission of the USGS is to provide geologic, topographic, and hydrologic information that contributes to the wise management of the Nation's natural resources and that promotes the health, safety, and well being of the people. This information consists of maps, databases, and descriptions and analyses of the water, energy, and mineral resources, land surface, underlying geologic structure, and dynamic processes of the earth.

For the Oregon OCS study, the USGS acquired multibeam echo sounder and seafloor video data surrounding the proposed development site, which is $95 \mathrm{~km}^{2}$ in area and 15 miles offshore from Coos Bay. The development site had been surveyed by Solmar Hydro Inc. in 2013 under a contract with WindFloat Pacific. The USGS subsequently produced a bathymetry digital elevation model and a backscatter intensity grid that were merged with existing data collected by the contractor. The merged grids were published along with visual observations of benthic geo-habitat from the video data in an associated USGS data release (Cochrane and others, 2015).

This report includes the results of analysis of the video data conducted by Oregon State University and the geo-habitat interpretation of the multibeam echo sounder (MBES) data conducted by the USGS. MBES data was published in Cochrane and others (2015). Interpretive data associated with this publication is published in Cochrane (2017). All the data is provided as geographic information system (GIS) files that contain both Esri ArcGIS geotiffs or shapefiles. For those who do not own the full suite of Esri GIS and mapping software, the data can be read using Esri ArcReader, a free viewer that is available at http://www.esri.com/software/arcgis/arcreader/index.html (last accessed August 29, 2016). Web services, which consist of standard implementations of ArcGIS representational state transfer (REST) Service and Open Geospatial Consortium (OGC) GIS web map service (WMS), also are available for all published GIS data. Web services were created using an ArcGIS service definition file, resulting in data layers that are symbolized as shown on the associated report figures. Both the ArcGIS REST Service and OGC WMS Service include all the individual GIS layers. Data layers are bundled together in a map-area web service; however, each layer can be symbolized and accessed individually after the web service is ingested into a desktop application or web map. Web services

\footnotetext{
${ }^{1}$ U.S. Geological Survey.

${ }^{2}$ Oregon State University.
} 
enable users to download and view data, as well as to easily add data to their own workflows, using any browser-enabled, standalone or mobile device.

Though the surficial substrate is dominated by combinations of mud and sand substrate, a diverse assortment of geomorphologic features are related to geologic processes-one anticlinal ridge where bedrock is exposed, a slump and associated scarps, and pockmarks. Pockmarks are seen in the form of fields of small pockmarks, a lineation of large pockmarks with methanogenic carbonates, and areas of large pockmarks that have merged into larger variously shaped depressions. The slump appears to have originated at the pockmark lineation. Video-supervised numerical analysis of the MBES backscatter intensity data and vector ruggedness derived from the MBES bathymetry data was used to produce a substrate model called a seafloor character raster for the study area. The seafloor character raster consists of three substrate classes: soft-flat areas, hard-flat areas, and hard-rugged areas. A Coastal and Marine Ecological Classification Standard (CMECS) geoform and substrate map was also produced using depth, slope, and benthic position index classes to delineate geoform boundaries. Seven geoforms were identified in this process, including ridges, slump scars, slump deposits, basins, and pockmarks.

Statistical analysis of the video data for correlations between substrate, depth, and invertebrate assemblages resulted in the identification of seven biomes: three hard-bottom biomes and four softbottom biomes. A similar analysis of vertebrate observations produces a similar set of biomes. The biome between-group dissimilarity was very high or high. Invertebrates alone represent most of the structure of the whole benthic community into different assemblages. A biotope map was generated using the seafloor character raster and the substrate and depth values of the biomes. Hard substrate biotopes were small in size and were located primarily on the ridge and in pockmarks along the pockmark lineation. The soft-bottom bitopes consisted of large contiguous areas delimited by isobaths. 


\section{Introduction}

The proposed floating windfarm site that is the subject of this investigation is situated 15 miles off Coos Bay on the upper slope in water depths of 200 to $600 \mathrm{~m}$ (fig. 1). The slope in the study area and of the Oregon and Washington coast in general is part of a forearc basin formed by oblique subduction of the Faralon Plate beneath North America beginning in the middle Eocene. Based on tidalmarsh records of subsidence, there have been 12 great subduction earthquakes in the last 6,700 years, most of which were ruptures of the entire subduction zone (Witter and others, 2003). Deformation of the slope initiates with reverse faulting and anticlinal folding at the base of the slope above the subducting oceanic plate (Kulm and Fowler, 1974). As accretion continues, the bathmetric basins between folds fill with sediment from the continent, the faults steepen, and the folds shorten (Kulm and Fowler, 1974). The upper slope and shelf consists of modern sediment unconformably overlying an extensively folded and faulted accretionary complex.

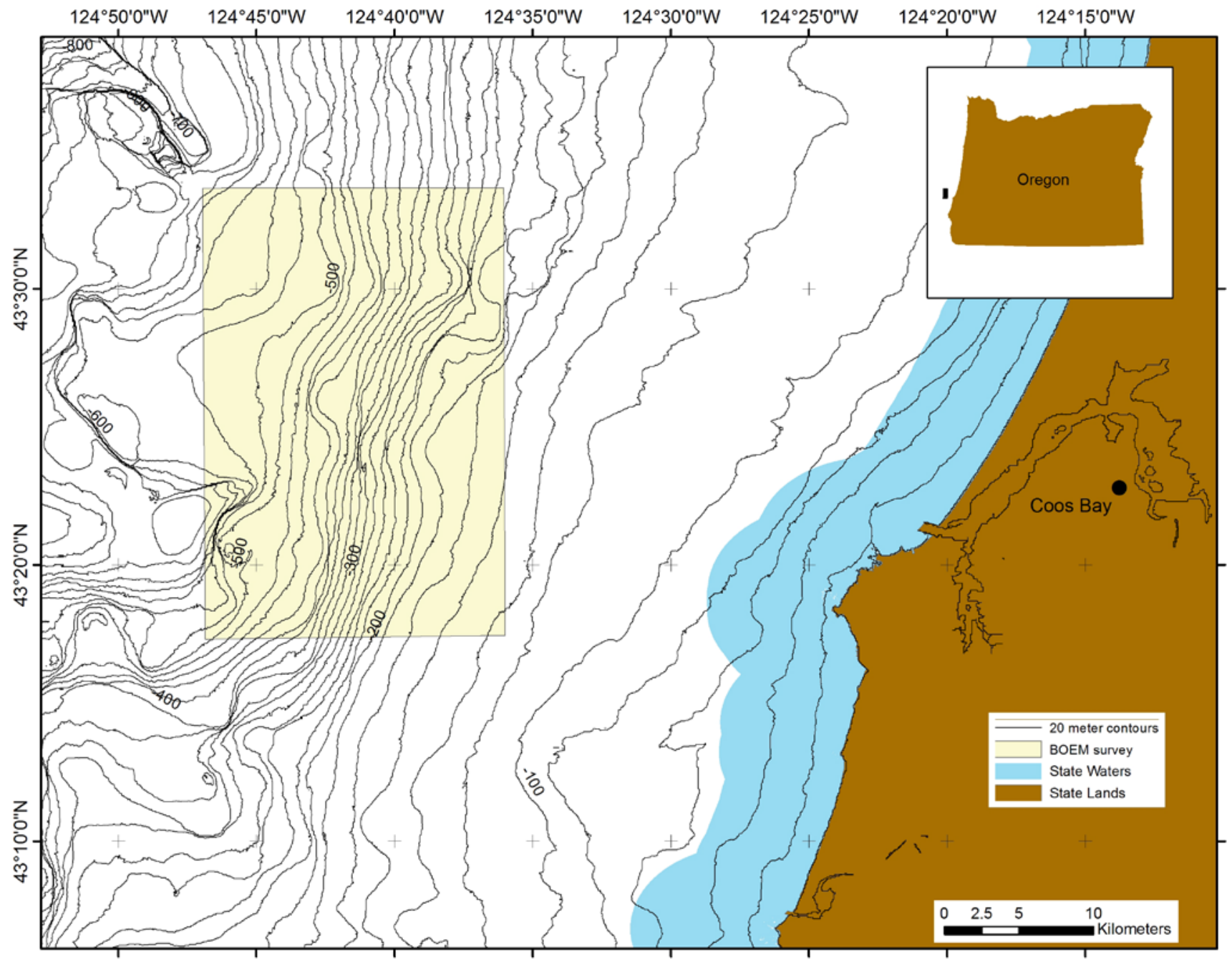

Figure 1. Map showing the location of the proposed floating wind energy farm. 
In the study area, the near-surface geologic units consist of recent sediment overlying Quaternary bedrock (Clarke and others, 1985). Middle Miocene melanges formed during a period of less oblique and, therefore, more accretionary convergence underly the Quaternary rocks and outcrop on the seafloor, where they have been uplifted along thrust faults that trend north-northeast (Snavely, 1987). Organic material in these thrust-faulted and folded Miocene sedimentary rocks is the source of most of the petroleum and gas that is stored in folds or seeps along faults on the shelf and upper slope along the Oregon and Washington coast (Snavely, 1987). The study area is also bounded to the north and south by active west-northwest strike-slip faults that may originate in the subducting Juan de Fuca Plate and represent left-lateral deformation resulting from the present oblique northeast-directed subdduction (Goldfinger and others, 1997).

Regional active-structure maps for the Oregon shelf and slope were produced and are updated by the Oregon State University Active Tectonics and Seafloor Mapping Lab (http://activetectonics.coas.oregonstate.edu) using geophysical or sampling data available at the time. These data are updated when new data are available. Goldfinger and others (2014) modeled the distribution of substrates in the floating wind energy farm area. The model is based on the legacy seismic data and sampling data from the 1960s. The model predicts mud in a low synclinal area and sandy mud on two surrounding northeast-trending anticlinal highs. Based on seismic data, Clarke and others (1985) estimated the maximum thickness of sediment in the syncline to be $165 \mathrm{~m}$ just west of the study area.

Essential Fish Habitat has been modeled off Oregon using any and all available data (http://www.westcoast.fisheries.noaa.gov/maps_data/essential_fish_habitat.html); however, the proposed wind energy area had not been previously surveyed with a MBES. Several benthic habitat studies, based on underwater video images, have already been carried out at a few places on the Oregon and Washington continental shelf (Hannah and others, 2010, 2013; Hemery and Henkel, 2015, 2016; Hixon and Tissot, 2007; Stein and others, 1992; Strom, 2006; Tissot and others, 2007), none included the floating wind energy farm area.

Hixon and Tissot (2007) and Hannah and others (2010, 2013) compared trawled versus untrawled mud assemblages at two locations on the Oregon continental shelf (respectively, Coquille Bank and Nehalem Bank). Diversity and abundance of fish species, as well as abundance of invertebrates, were higher in untrawled soft-sediment areas; however, the diversity of invertebrates was higher in heavily trawled sections due to a greater diversity of scavenger organisms (Hixon and Tissot, 2007). The abundance of sea whips was low in heavily trawled areas but increased rapidly after the sector was closed to trawling, providing more structure to the habitat (Hannah and others, 2010, 2013). Tissot and others (2007) described the invertebrate and fish assemblages at a single outer continentalshelf reef off Oregon (Heceta Bank), while Stein and others (1992) described the fish-habitat associations at that same outer shelf outcrop. They identified four to five habitats, mainly based on depth and type of substrates: shallow rock ridges and large boulders ( $<100 \mathrm{~m}$ deep) with assemblages characterized by basket stars, juvenile and adult rockfishes, and lingcod; mid-depth small boulder to cobbles (100-150 m) with assemblages characterized by crinoids, brittle stars, and four species of rockfishes; deep cobbles (150-200 m) also dominated by crinoids, brittle stars, and various small rockfish species; and deep mud slopes (>200 m) characterized by sea urchins, sea cucumbers, thornyhead, and flatfishes (Tissot and others, 2007). In Stein and others (1992), rock ridges and boulders constituted two different habitats, but this study was solely based on fish assemblages, without taking into account any invertebrates.

Strom (2006) and Hemery and Henkel (2015, 2016) focused on benthic mega-invertebrates. Strom (2006) summarized the distribution of structure-forming invertebrates at multiple sites, mostly 
rocky reefs, along the continental margin of the Oregon and Washington shelf and observed regional differences: Daisy Bank, mainly composed of boulders and cobbles, appeared to be a suitable habitat for sponges, while Heceta Bank and Siltcoos Reef were dominated by crinoids. Consolidated sediment habitats showed higher densities of invertebrates than unconsolidated sediment habitats, except in mudpebble habitats, where densities were the highest owing to an abundance of sea urchins and sea pens. More recently, Hemery and Henkel (2015, 2016) described the mega-invertebrate benthic assemblages (sessile and motile) of soft and hard bottoms at three rocky reefs of the middle Oregon and Washington continental shelf. Assemblages differed depending on depth (50-80 m vs. 100-120 m) and relief type (consolidated rocks vs. unconsolidated rocks and soft sediments). Consolidated rock assemblages were made of a combination of various sponges, gorgonians, sea anemones, and echinoderms; assemblages on unconsolidated rocks were characterized by sea anemones and burrowing brittle stars at Grays Bank, and by sponges and echinoderms at Bandon-Arago; soft sediment assemblages were dominated by sea whips and burrowing brittle stars at Grays Bank and Siltcoos Reef, with the addition of pink shrimps and sea stars at Siltcoos Reef, and by sponges, gorgonians, and echinoderms at Bandon-Arago.

The objective of this study was to produce habitat characterizations of the study area, including a seafloor character map (Cochrane, 2008) and a Coastal and Marine Ecological Classification System (CMECS) map with geoform and substrate attributes (Madden and others, 2008). Oregon State University was contracted to describe the benthic assemblages (sessile and motile, fishes and invertebrates) using the video acquired with a towed camera sled. Organisms were identified to the lowest taxonomic level possible and assemblages were described related to the nature of the seafloor and the depth. The assemblages were then related to the CMECS map attributes to produce a CMECS biotope map of the study area.

\section{Data Acquisition}

\section{Multibeam Echo Sounder Survey}

Both the USGS and Solmar Hydro Inc. surveys used a 100-kHz Reson 7111 multibeam echo sounder. The USGS mapping was completed between August 20 and September 1, 2014, aboard the USGS R/V Parke Snavely (U.S. Geological Survey field activity 2014-607-FA). During the mapping mission, an Applanix Position and Motion Compensation System for Marine Vessels (POS/MV, 320, v4) was used to accurately position the vessel during data collection; it also accounted for vessel motion such as heave, pitch, and roll with input from Differential Global Positioning System (DGPS) aided positional navigation from dual Trimble model 4000 DGPS receivers. Soundings were corrected for vessel motion using the position and orientation system for marine vessels (POS/MV) data, for variations in water-column sound velocity using data from an Applied Microsystems SVPlus velocimeter, and for tides using verified tide data from the Coos Bay tide station (9432780).

Reson s7k files were imported into Caris HIPS and SIPS hydrographic data processing software. Lever arm offsets and patch test values were applied to the data in the merge process. Data were cleaned for obvious erroneous soundings and a CUBE base surface was generated at 12-m spatial resolution. The surface was exported as an ASCIIRaster file in UTM10, WGS84 coordinates referenced to mean lower low water (MLLW). Damage to the MBES occurred during the operation and ripple-like patterns and straight lines (fig. 2) in some parts of the map area are artifacts caused by lower quality data coming from the damaged transducer. 


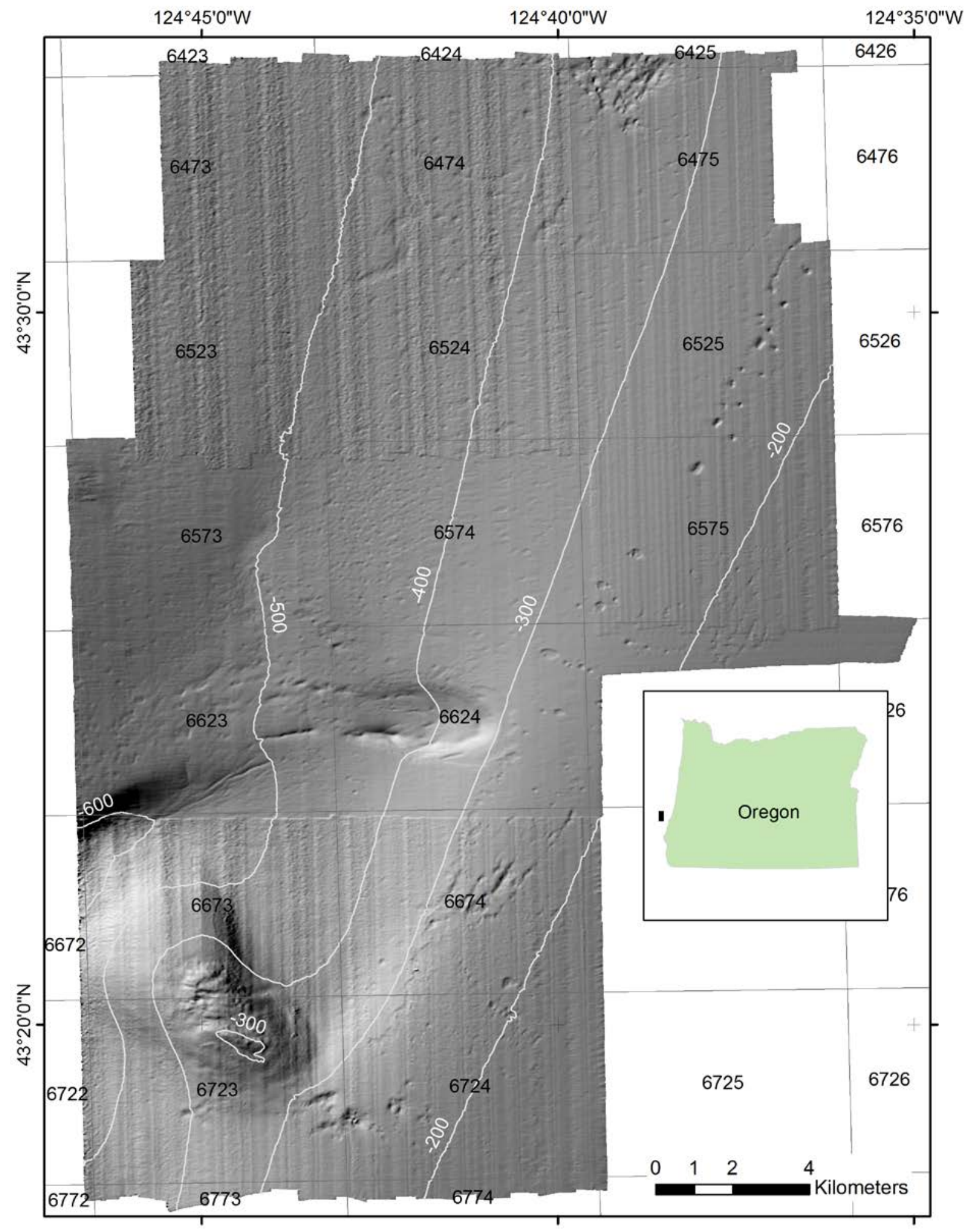

Figure 2. Hillshade image produced from the merged multi-beam echo-sounder (MBES) bathymetry digital elevation model. Contours shown in white are depth in meters. Grid shown is the BOEM lease block grid and block numbers. 
Acoustic-backscatter data were processed using Fledermaus. The Caris HIPS and SIPS processed line files were exported as GSF files. These files along with their paired s7k files were imported into Fledermaus FMGT backscatter processing software. Snippets data were processed by applying an angle varying gain (AVG) correction using the flat algorithm with a window size of 100 . Transmit and receive (Tx/Rx) power gain corrections were also applied. A mosaic was generated at 12m spatial resolution. The mosaic was exported as a Fledermaus SD file in UTM 10, WGS84 coordinates and then converted to an ASCIIRaster file.

The acoustic-backscatter imagery from the USGS and Solmar Hydro Inc. surveys were normalized using reclassification in ArcMap and merged. Backscatter intensity represents a complex interaction between the acoustic pulse and the seafloor, as well as characteristics within the shallow subsurface, providing a general indication of seafloor texture and composition. Backscatter intensity depends on the acoustic source level; the frequency used to image the seafloor; the grazing angle; the composition and character of the seafloor, including grain size, water content, bulk density, and seafloor roughness; and some biological cover. Harder and rougher bottom types such as rocky outcrops or coarse sediment typically return stronger intensities (high backscatter, lighter tones), whereas softer bottom types such as fine sediment return weaker intensities (low backscatter, darker tones).

\section{Video Survey}

Upon completion of the MBES survey a video survey was conducted with transects designed to validate the interpretations of sonar data to turn it into geologically and biologically useful information. The USGS towed a camera sled over 17 transects designed to identify substrate types and biota in a representative distribution of depth, backscatter intensity variation, and bathymetric complexity (fig. 3). There were 18 video transects that generated 11.6 hours of video; the mean length of time per transect was 38 minutes. The ground-truth survey took place September 6-9, 2014.

The sled was towed behind the boat at a more-or-less regular speed of 1 knot. When possible, the sled was kept at approximately $1 \mathrm{~m}$ above the bottom to provide images of good quality to identify and enumerate the benthic organisms. The R/V Parke Snavely is a 35' boat, and swell conditions caused boat motion that affected the camera altitude significantly. The sled was equipped with one color still camera and two color video cameras: one facing downward and perpendicular to the dorsal surface of the sled, and the other facing outward, slightly angled from the dorsal surface. The sled was equipped with sizing lasers, $10 \mathrm{~cm}$ apart, for each camera. The position of the sled on the bottom was estimated from the position of the boat at the surface. 


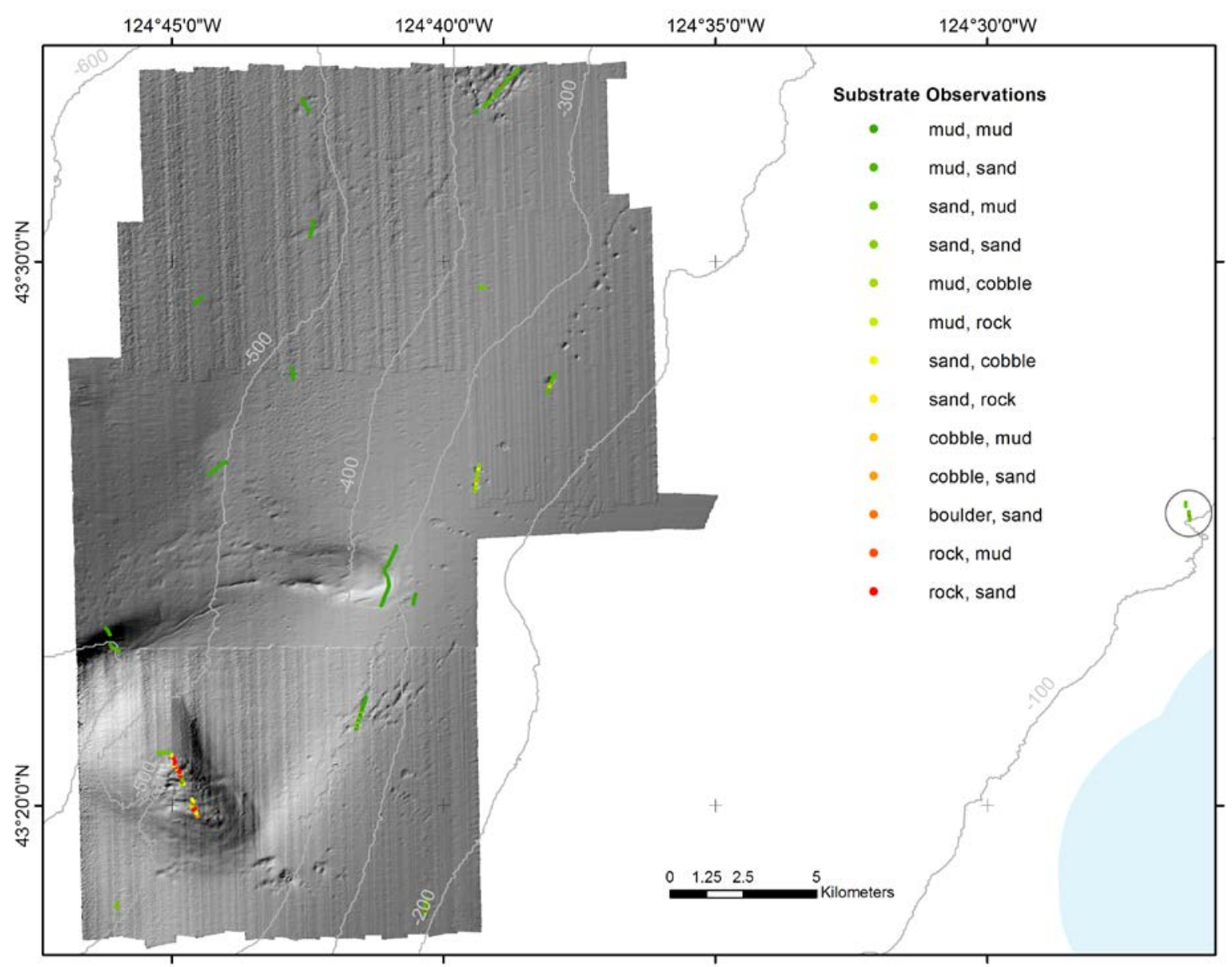

Figure 3. Map showing location and length of the video transects overlain on the hillshade image. Colored dots represent the combinations of primary and secondary substrate observed at points along the video transect. Hundred-meter isobaths are shown in light gray. Circle on right edge surrounds shallow water video transect.

\section{Geological Analysis}

\section{Video Analyses}

The camera-sled transects (fig. 3) are sited to visually inspect areas representative of the full range of bottom hardness and rugosity in the map area. The video is streamed in real time to the research vessel, where the video is recorded and USGS scientists record visual estimates of the substrate on the seafloor. While the camera is deployed, observations of primary substrate and secondary substrate are recorded for a 10-second period once every minute, using the protocol of Anderson and others (2007). Primary and secondary substrate, by definition, constitute greater than 50 and 20 percent of the seafloor, respectively, during an observation (Tissot and others, 2006). The grain-size values that differentiate the substrate classes are based on the Wentworth (1922) scale, and the sand, cobble, and boulder sizes are classified as in Wentworth (1922). However, the difficulty in distinguishing the finest divisions in the Wentworth (1922) scale during video observations made it necessary to aggregate some grain-size classes, as was done in the Anderson and others (2007) methodology: the granule and pebble sizes have been grouped together into a class called "gravel," and the clay and silt sizes have been grouped together into a class called "mud.” In addition, hard bottom and clasts larger than boulder size are classified as "rock." 
Figure 4 shows the locations of still images captured from the video as examples of the substrate classes observed; figures 5-12 show the screen captures. Despite the effort to observe hard-rugose substrate, the video survey data is predominantly soft bottom. Of the total of 575 observations, 482 were of combinations of mud and sand (figs. 5, 7), whereas 93 observations included some cobble, boulder, or low-rugosity bedrock (figs. 6, 8-12).

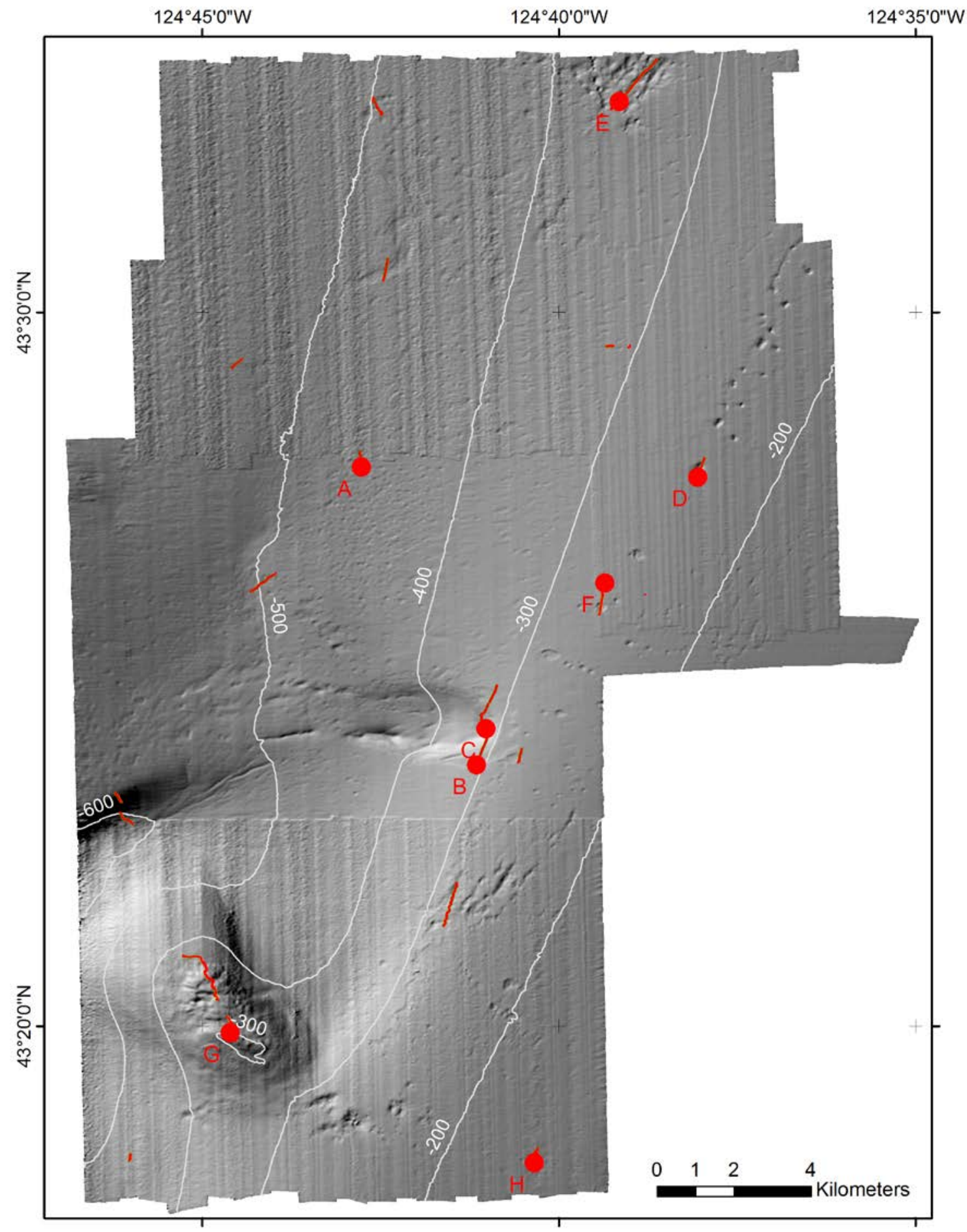

Figure 4. Map showing locations of still images captured from video. Large red labeled dots indicate still images shown in later figures; small red dots show video tracklines. 


\section{Figure 5. Image $A$ on figure 4. Mud bottom with bioturbation. Distance between lasers is $10 \mathrm{~cm}$.}

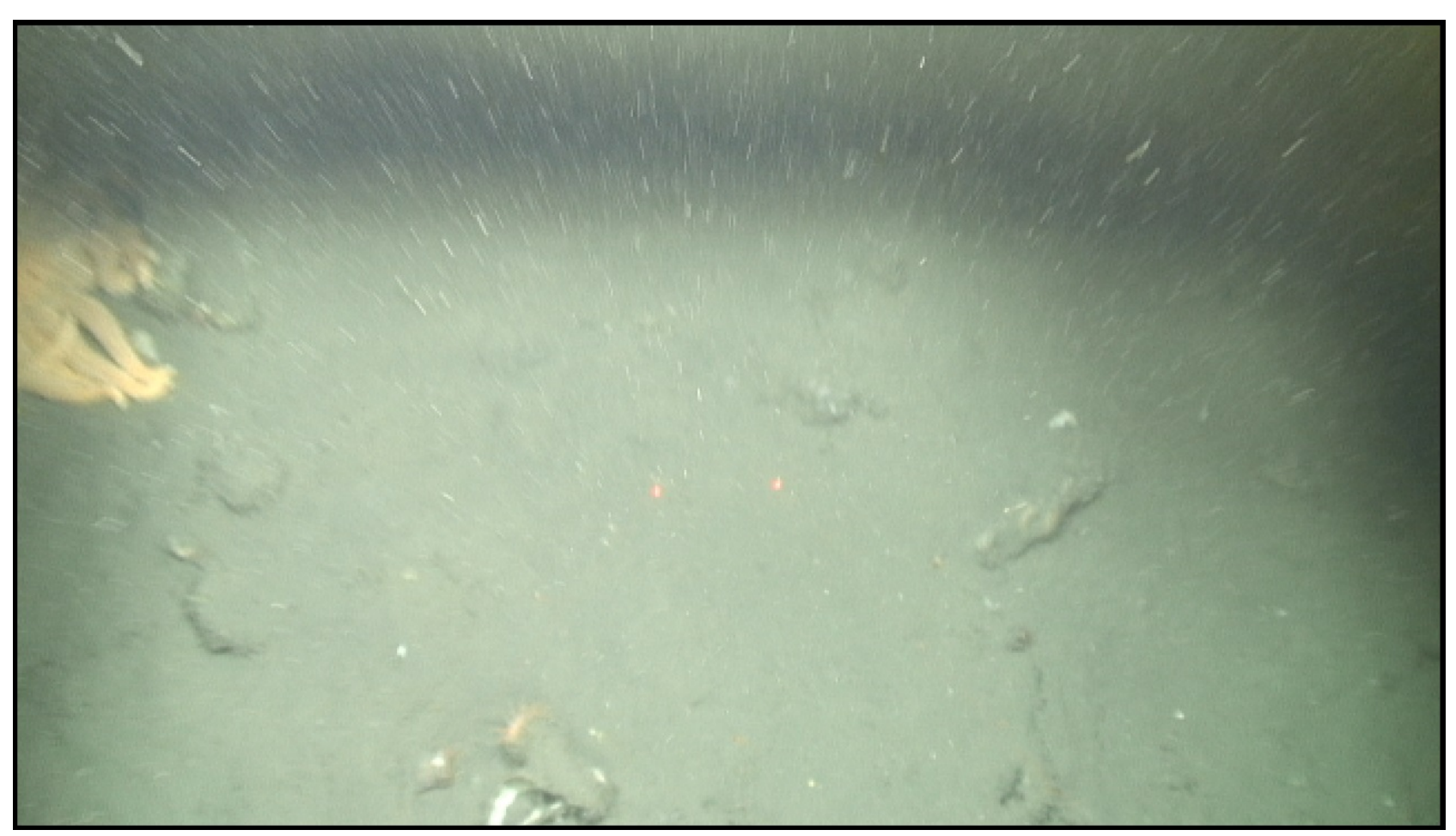

Figure 6. Image B on figure 4. Mud bottom with cobble-sized clasts that may be fractured methanogenic carbonates. Distance between lasers is $10 \mathrm{~cm}$. 


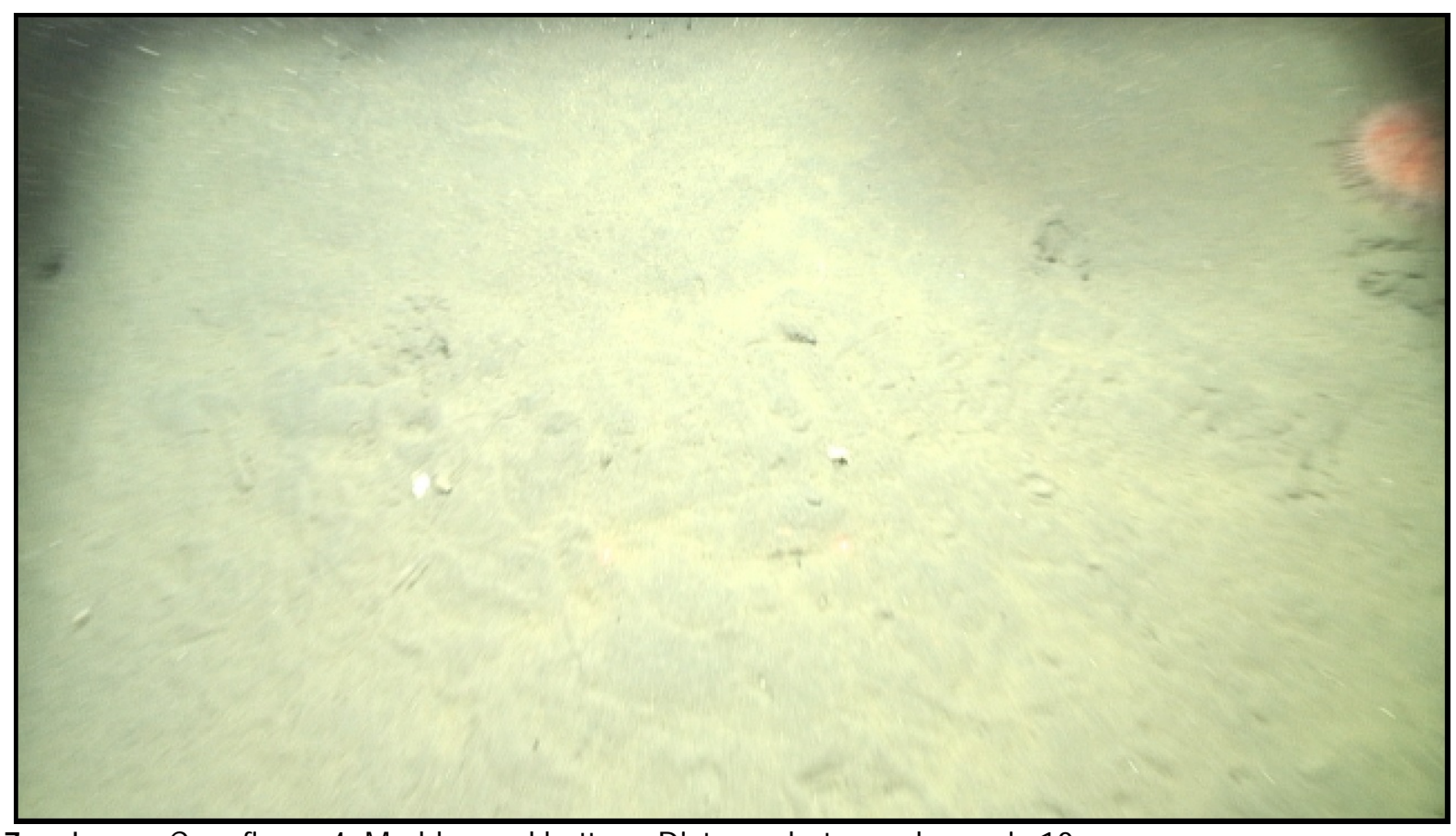

Figure 7. Image $\mathrm{C}$ on figure 4. Muddy sand bottom. Distance between lasers is $10 \mathrm{~cm}$.

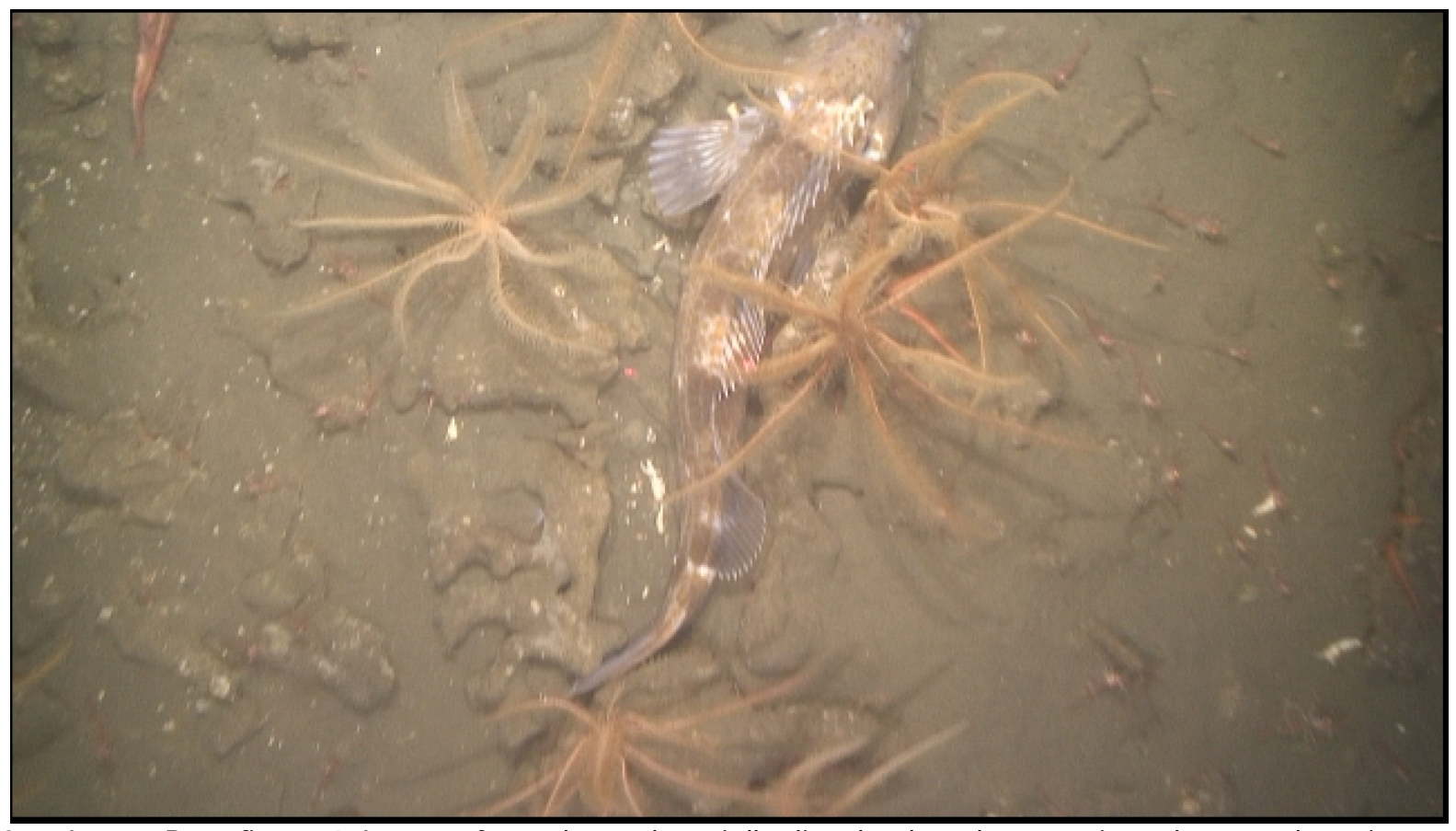

Figure 8. Image $\mathrm{D}$ on figure 4. Image of angular and partially dissolved methanogenic carbonate clasts in a pockmark. Distance between lasers is $10 \mathrm{~cm}$. 


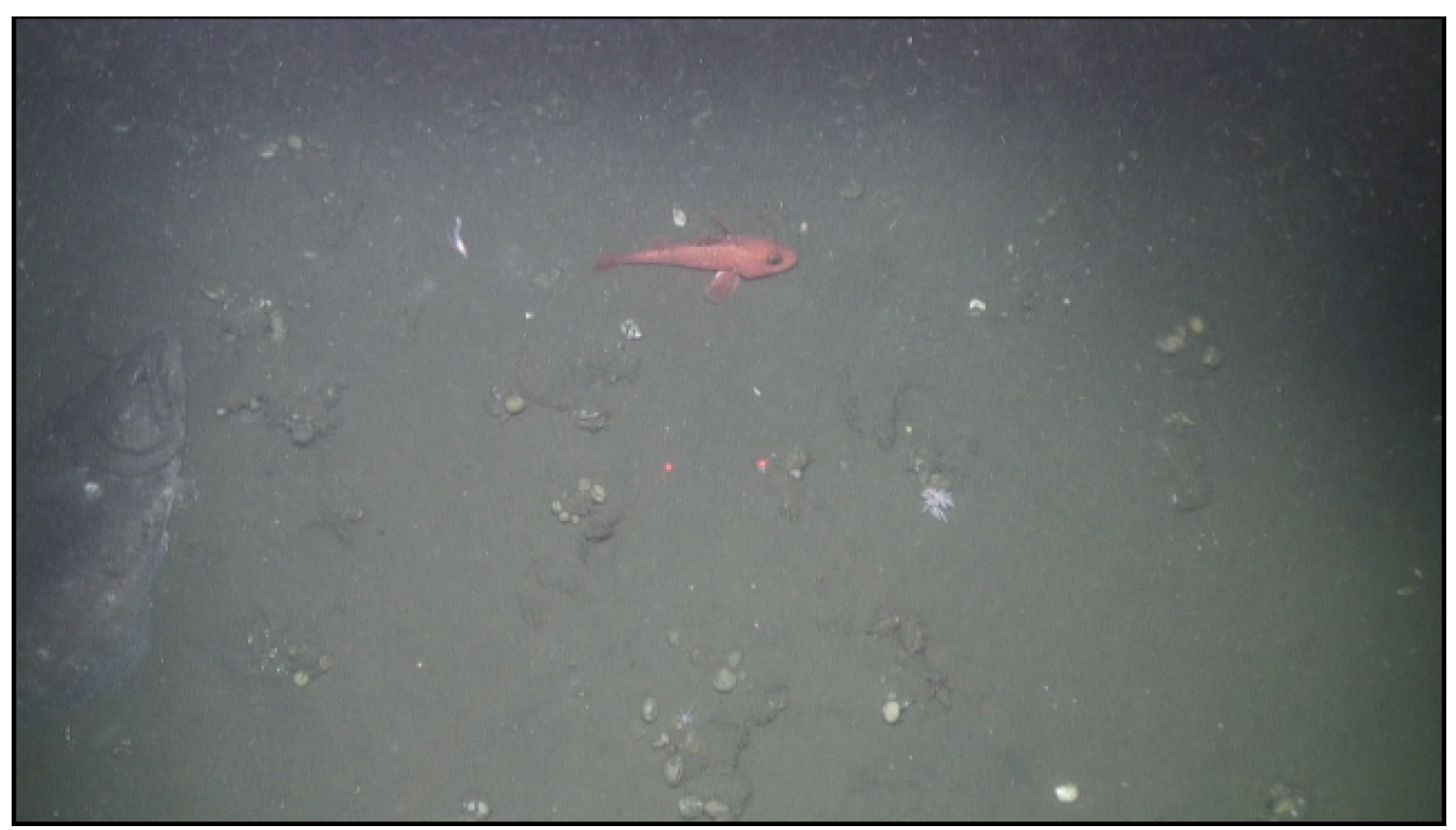

Figure 9. Image E on fig. 4. Image of angular and partially dissolved methanogenic carbonate clasts in an area of merged pockmarks. Distance between lasers is $10 \mathrm{~cm}$.

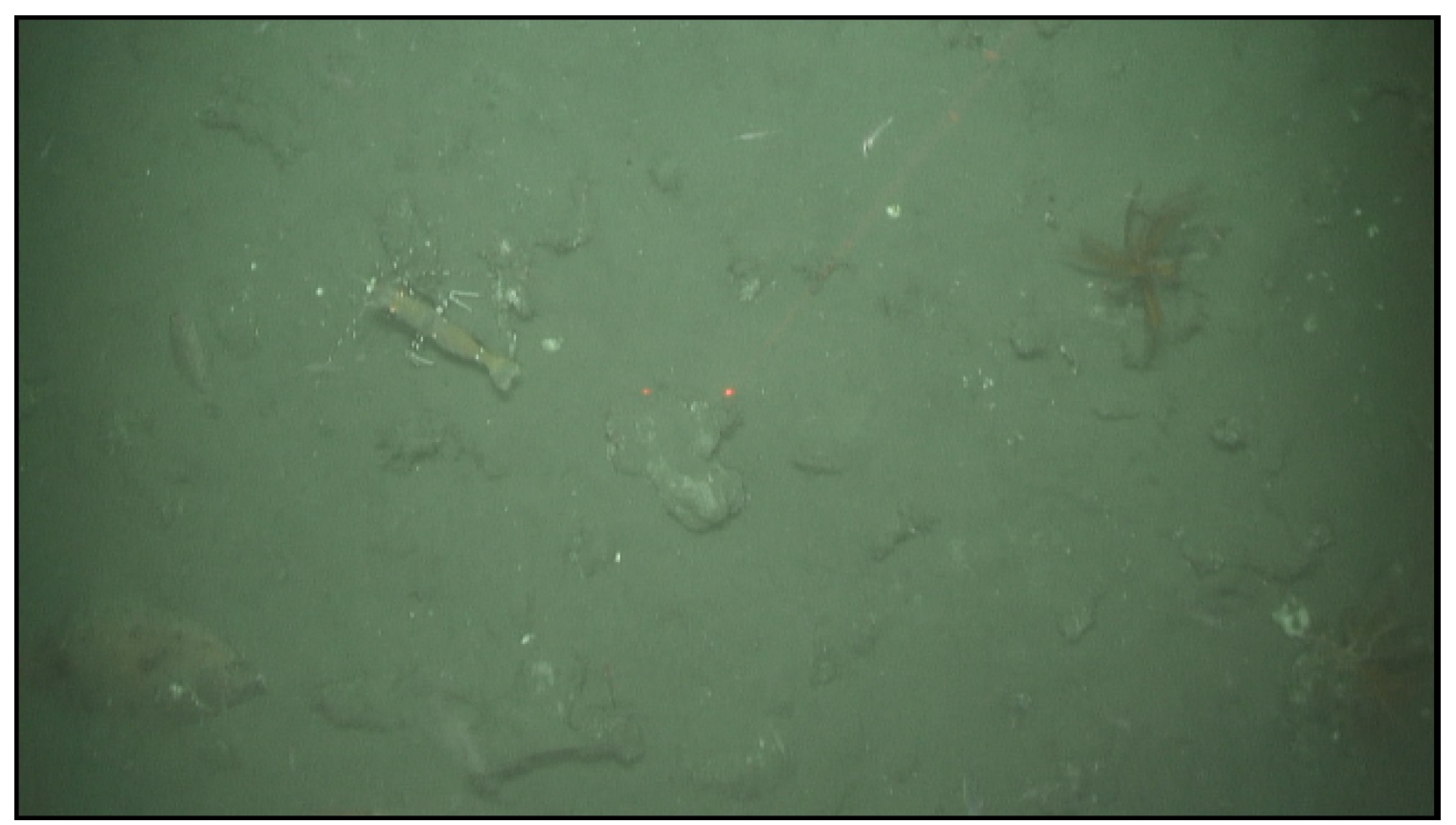

Figure 10. Image F on fig. 4. Image of angular and partially dissolved methanogenic carbonate clasts in a pockmark. Distance between lasers is $10 \mathrm{~cm}$. 


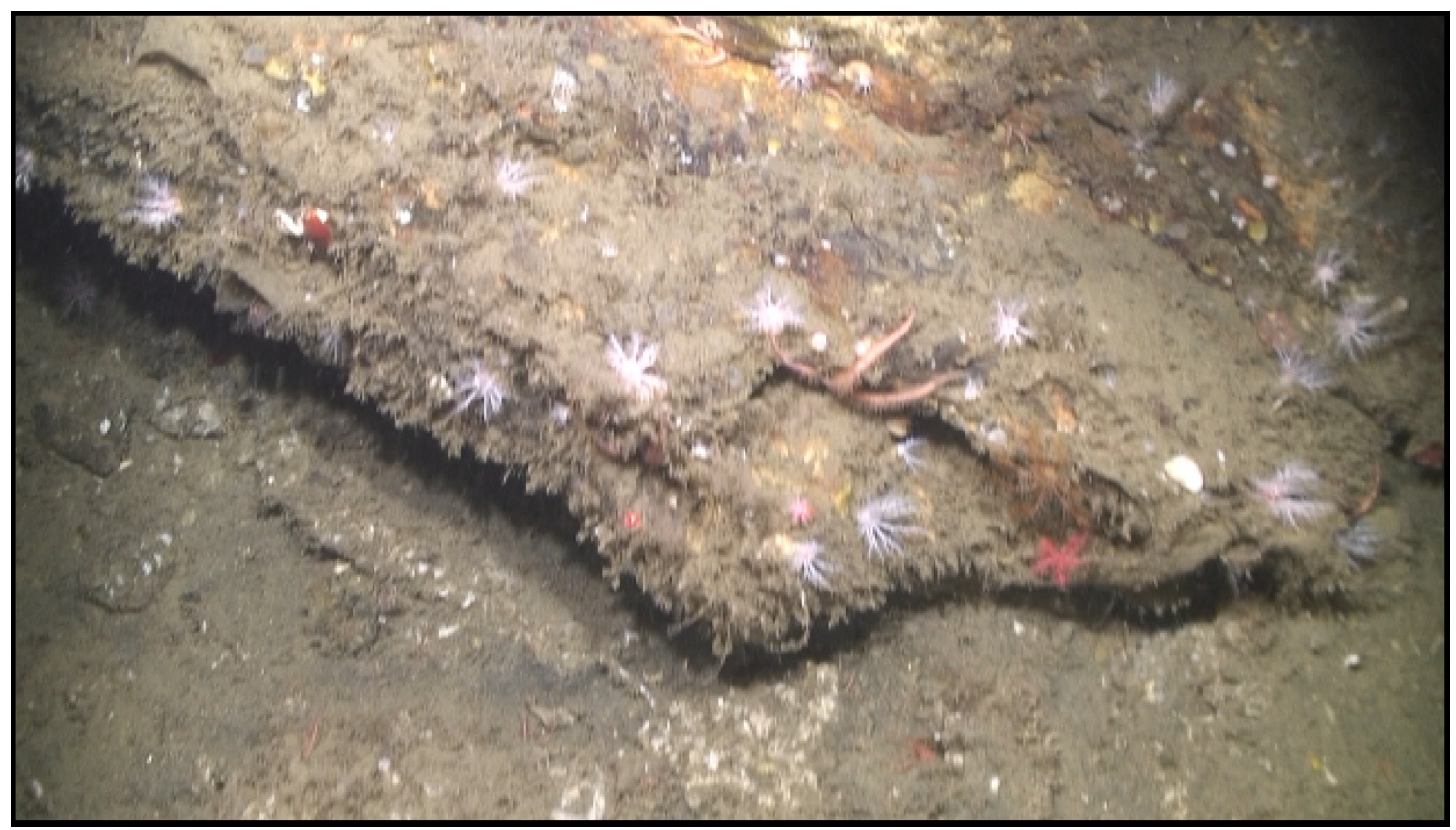

Figure 11. Image $\mathrm{G}$ on figure 4. Bedrock outcrop on ridge feature. Distance between lasers is $10 \mathrm{~cm}$.

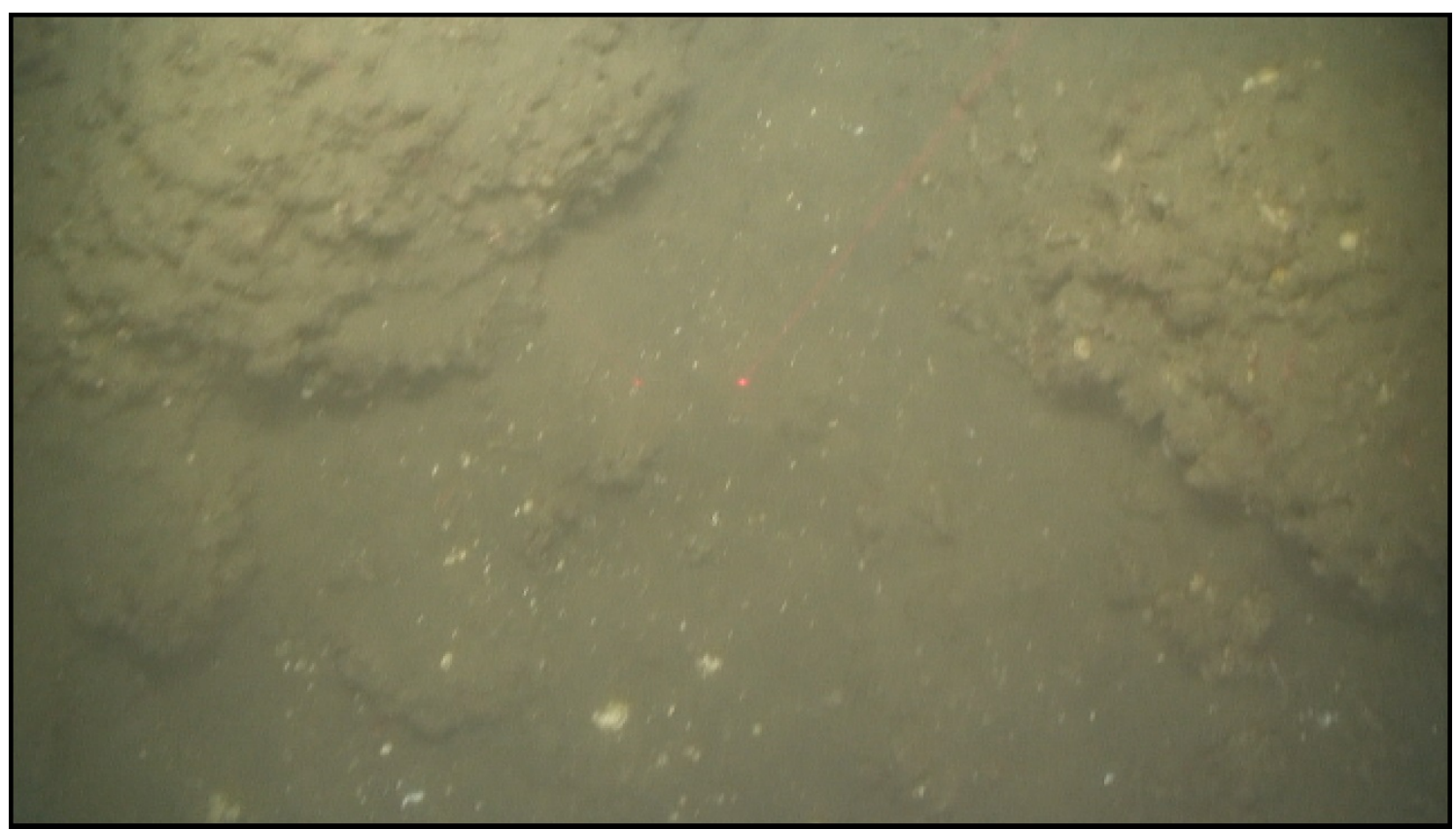

Figure 12. Image $\mathrm{H}$ on figure 4. Bedrock outcrop on shelf. Distance between lasers is $10 \mathrm{~cm}$. 


\section{Seafloor Character Classification}

The seafloor-character classification was produced using video-supervised maximum-likelihood classification of the bathymetry and backscatter intensity from the MBES survey, following the method described by Cochrane (2008). The two variants used in this classification were backscatter intensity and derivative rugosity. The rugosity calculation was performed using the Terrain Ruggedness (VRM) tool within the Benthic Terrain Modeler toolset v. 3.0 (Wright and others, 2012; available at http://esriurl.com/5754). The classification was supervised using the geological analyses of the video data. For supervision, the observations of primary and secondary substrate were converted to seafloor character classes according to the conversion scheme shown in table 1.

Table 1. Conversion table showing how video observations of primary substrate (more than $50 \%$ seafloor coverage) and secondary substrate (more than 20\% seafloor coverage) are grouped into seafloor-character-map Classes I, II, and III for use in seafloor character classification.

\begin{tabular}{|c|c|}
\hline $\begin{array}{c}\text { Primary substrate } \\
\text { component }\end{array}$ & $\begin{array}{c}\text { Secondary substrate } \\
\text { component }\end{array}$ \\
\hline \multicolumn{2}{|c|}{ Soft flat combinations: } \\
\hline mud & mud \\
\hline mud & sand \\
\hline sand & mud \\
\hline sand & sand \\
\hline \multicolumn{2}{|c|}{ Hard flat combinations: } \\
\hline mud & cobble \\
\hline sand & cobble \\
\hline cobbles & mud \\
\hline cobbles & sand \\
\hline \multicolumn{2}{|c|}{ Hard rugose combinations: } \\
\hline mud & rock \\
\hline sand & rock \\
\hline boulder & sand \\
\hline rock & mud \\
\hline rock & sand \\
\hline rock & rock \\
\hline
\end{tabular}

The only observations of rugose seafloor in the video used for supervision of the classification were located on the ridge in the southern part of the study area. Class III was determined where rugosity calculated from the MBES data exceeded 0.0003, which was the rugosity for a small area on the ridge where bedrock outcrop was observed. After classification, the seafloor character raster (fig. 13) was edited by hand to remove artifacts produced by noise. The area was dominated by soft-flat sediments (99.00 percent; 28,593,024 $\left.\mathrm{m}^{2}\right)$. The remainder of the area was hard flat $\left(0.89\right.$ percent; $\left.257,784 \mathrm{~m}^{2}\right)$ and hard rugose (0.01 percent; 28,644 $\left.\mathrm{m}^{2}\right)$ substrates. 


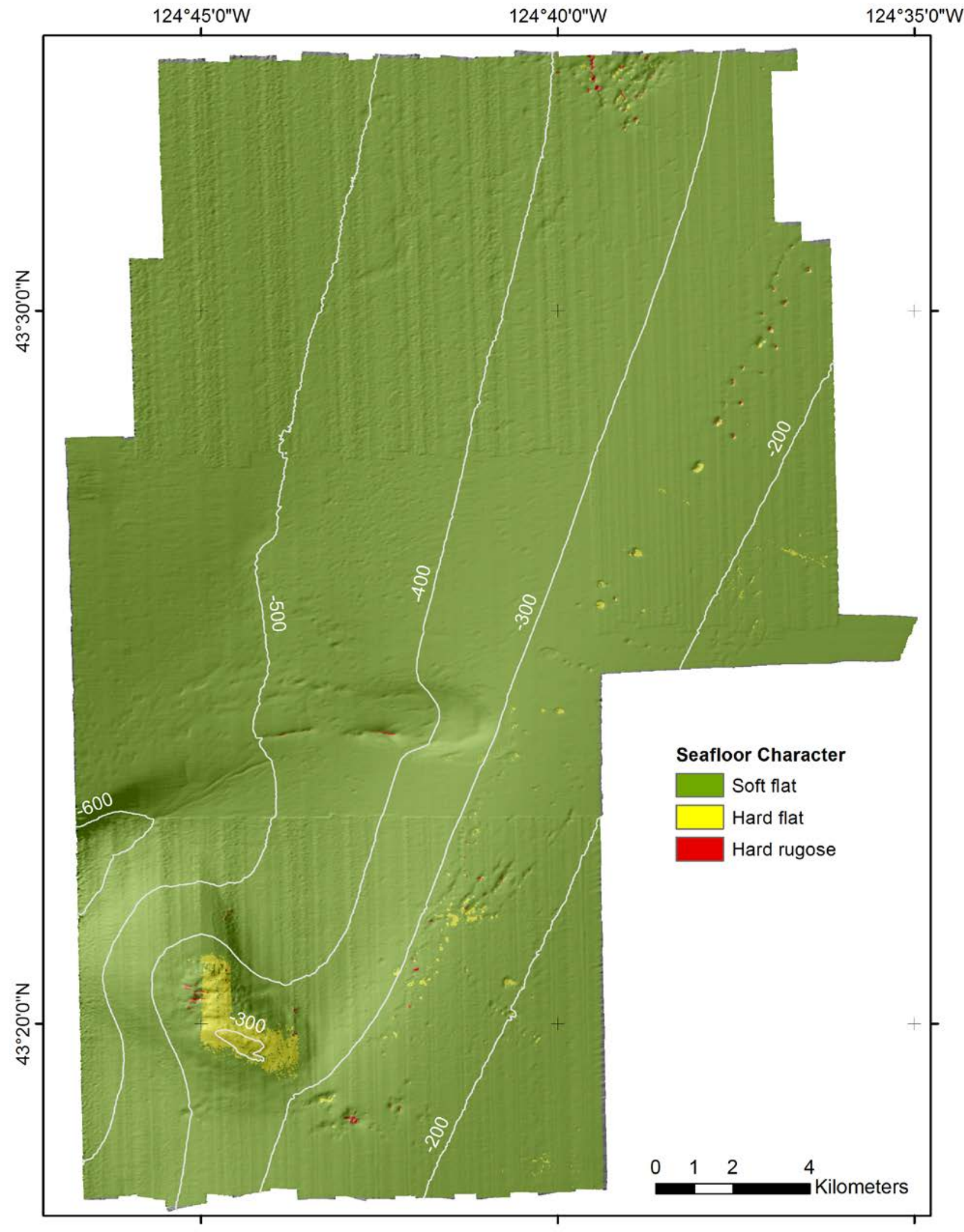

Figure 13. Image of seafloor-character raster. 


\section{CMECS Geoforms}

Geoform polygons were produced for the map area using a combination of benthic position index (BPI) and slope. BPI values were calculated using an annulus with an inner radius of $36 \mathrm{~m}$ and an outer annulus of $72 \mathrm{~m}$. The radii were determined based on the scale of geoforms identified visually in the hillshade image (fig. 2), which include pockmarks, a slump with a slump scar and submarine slide deposits, and a bedrock ridge. To produce a continuous CMECS polygon geoform layer, the BPI raster was classified using values of -43 to -0.7 for all depressions, values of -0.7 to 3.0 for flats, and 3.0 to 32 for ridges. A slope raster was similarly classified into polygons for CMECS slope classes (Madden and others 2008). Two slope classes were present in the area: flat areas with a slope of $0-5^{\circ}$ and sloping areas with a slope of $5-30^{\circ}$. The BPI and slope polygons were merged and then a geoform attribute was assigned from the geoform list in Madden and others (2008).

Eight geoforms were identified in the area (fig. 14). The most obvious features are a ridge in the southwest and a slump feature in the center of the study area. Numerous pockmarks are present. Large individual pockmarks and areas where numerous pockmarks have merged to create a large depression were distinguishable using BPI classification. There are also numerous smaller pockmarks throughout the map area so the entire flat shelf sedimented area is classified as a pockmark field.

A subtle increase in slope from $<2^{\circ}$ to the east to $\sim 3^{\circ}$ west of a north-northeast-trending lineation of pockmarks suggests some geologic structural control of the pockmark seepage. Angular cobble- and boulder-size clasts were observed in the video survey data collected over one of the larger pockmark depressions; these depressions are likely seep methanogenic carbonates that have broken up into clasts and show signs of dissolution (fig. 8). Fluid flow upward along thrust faults and associated seeps have been extensively studied on the Oregon slope since the 1980s (Kulm and others, 1986). Available seismic data (Triezenberg and others, 2016) was collected in the 1980s for petroleum resource analysis. Figure 15 is a section of a seismic profile that crosses the study area just north of the slump. No obvious surface structure underlying the pockmark lineation is visible in the profile, though some discontinuity of reflections may possibly be seen below the seafloor multiple in units that show convergent margin folding. The reflections above the folded units look like a drape of unconsolidated sediment. Folding can be seen clearly in the seismic data (fig. 15), however no obvious thrust faulting associated with the folds is seen in the seismic data in the study area. The northwest-trending ridge in the area was interpreted as an anticlinal fold structure without an associated thrust fault (Clarke and others, 1985). The large pockmark lineation coincides with the shelf break where there is a slight increase in slope and likely discontinuity in the underlying bedrock that may combine to focus diffuse flow of methanogenic fluids. 


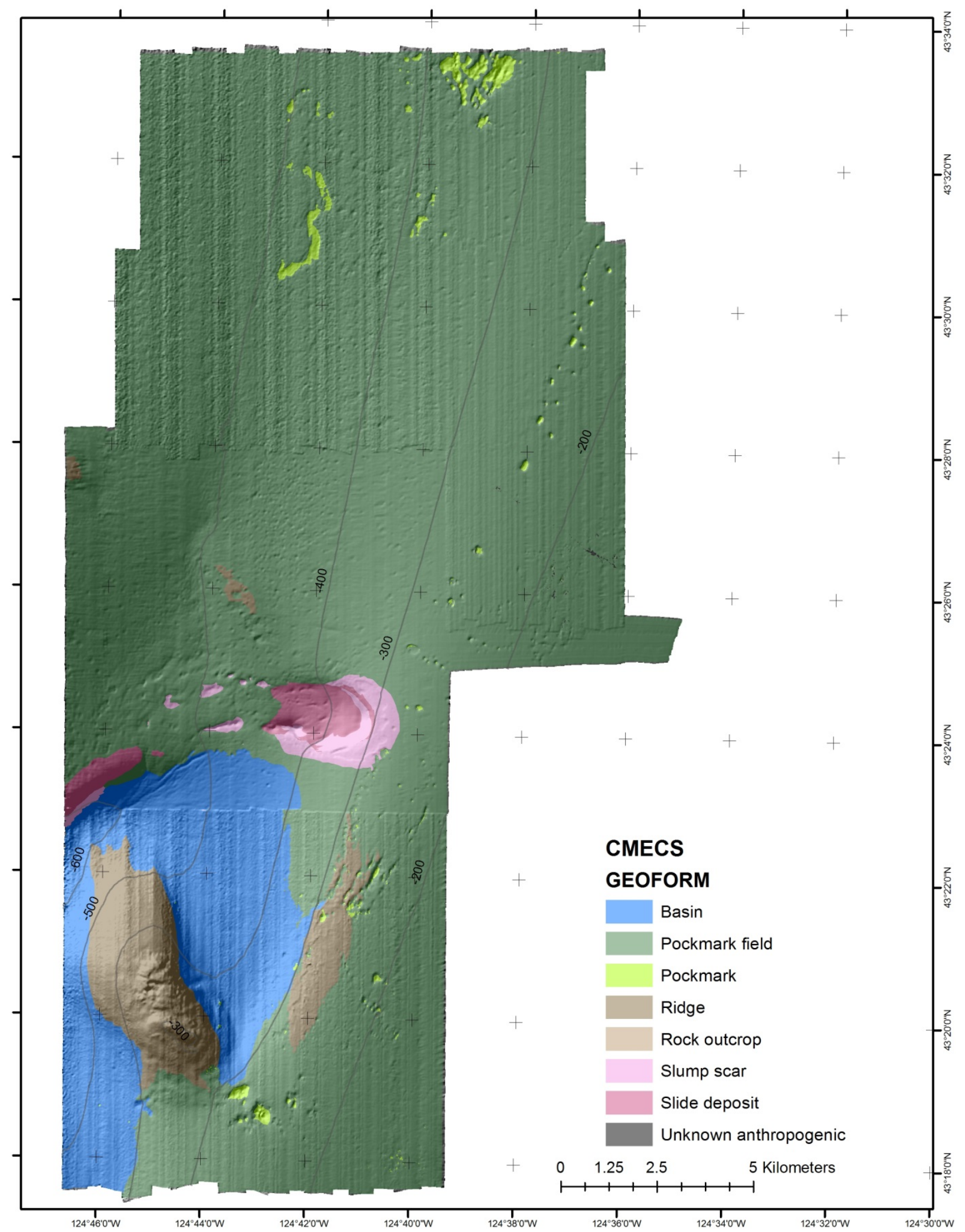

Figure 14. Image of CMECS geoforms. Unknown anthropogenic feature is a northwest-trending lineation on the east edge of the study area (north of lat $43^{\circ} 26^{\prime} 0^{\prime \prime} \mathrm{N}$.). 


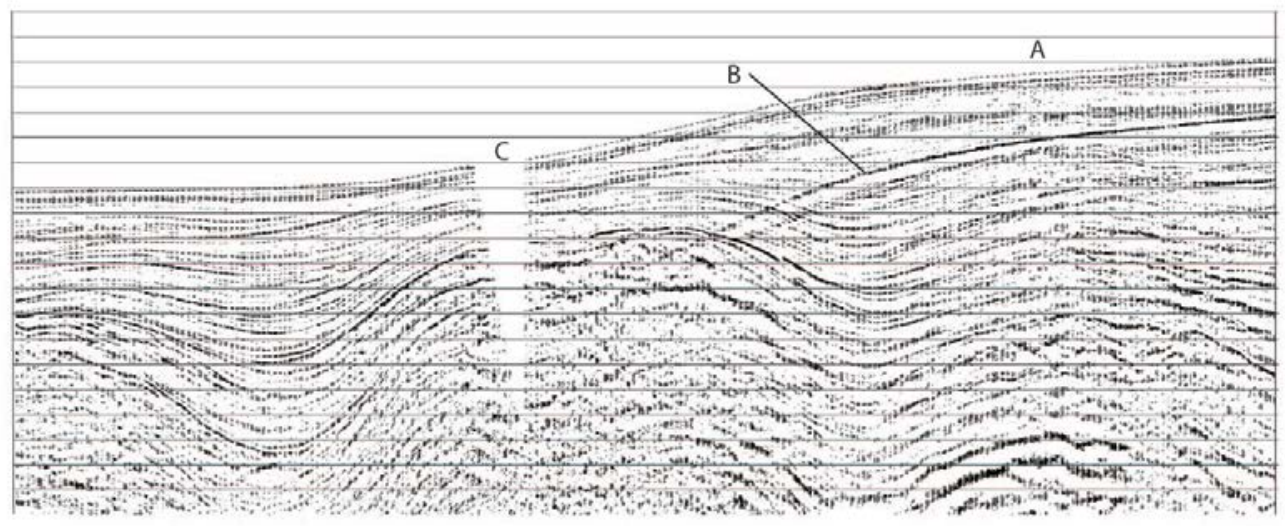

Figure 15. Section of east-west-oriented multichannel seismic profile across the mapped area just north of the slump feature. $A$ is located above the lineation of pockmarks. Line from B ends at the top of the seafloor multiple reflection. $C$ is located above a gap in the data.

The slump has initiated at the pockmark lineation, which suggests that, in addition to the subtle increase in slope, seepage is also part of the slump initiation. Hovland and others (2002) describe several slumps that initiated adjacent to or just downslope of pockmark areas indicating failure is, in part, due to increased fluid pressure in the sediment. The submarine slide deposition then occurred in a depression partly controlled by the location of the northwest-trending ridge into an associated syncline mapped by Clark and others (1985). These convergent margin-slope structures are aligned obliquely to the shelf break indicating there must be some structural discontinuity along the break but identifying that structure and origin of the pockmark lineation will require higher resolution seismic data.

\section{Fish Identification}

The video data were processed for the identification of fish species by BOEM marine ecologist Donna Schroeder (written commun., 2017). The species observed are shown in table 2.

Table 2. Fish species observed in the Oregon OCS study video data.

\begin{tabular}{ll}
\hline \multicolumn{1}{c}{ Fish, common name } & \multicolumn{1}{c}{ Scientific name } \\
\hline Sablefish & Anoplopoma fimbria \\
Pacific Hagfish & Eptatretus stoutii \\
Rex Sole & Glyptocephalus zachirus \\
Spotted ratfish & Hydrolagus colliei \\
Bigfin eelpout & Lycodes cortezianus \\
Black eelpout & Lycodes diapterus \\
Slender Sole & Lyopsetta exilis \\
Dover Sole & Microstomus pacifica \\
English sole & Parophrys vetulus \\
California skate & Raja inornata \\
Longnose skate & Raja rhina \\
Splitnose rockfish & Sebastes diploproa \\
Shortspine thornyhead & Sebastolobus alascanus \\
\hline
\end{tabular}




\section{Biological Analysis}

\section{Video Analyses}

Each video was watched a minimum of five times: (1) initial identification of every taxa observed during the 17 dives; (2) substratum identification; (3) sessile mega-invertebrate identification and enumeration; (4) motile mega-invertebrate identification and enumeration; and (5) fish identification and enumeration. Some stations with a denser invertebrate coverage necessitated one to three additional viewings. All the benthic epifauna and some endofauna taxa, showing recognizable body parts above the sediment, were recorded. Only the downward-facing videos were used to identify substratum patches and organisms; the outward facing videos were only used to help difficult identifications by providing a different view angle. All footage viewed by the downward-facing camera was considered "on-transect” if the sled's height above the seafloor was low enough to allow identification. Generally, video analysis followed guidelines established by Tissot (2008). Each observation entry was accompanied with a time code that was used to determine in which substratum patch a particular organism was found.

Substratum patches were identified based on the grain-size class estimated from the video footage and, for consolidated rocks, the relief angle, and the start and end times of each substratum patch were recorded. Each substratum patch was coded with two letters, refined from Stein and others (1992); the first letter indicates the primary substratum (comprising 50-80 percent of the area of the patch) and the second letter indicates the secondary substratum (comprising 20-50 percent of the area of the patch): $\mathrm{R}$ for ridge rock (angle $>30^{\circ}$ ), $\mathrm{F}$ for flat rock (angle $<30^{\circ}$ ), B for boulder $(>25.5 \mathrm{~cm}$ ), $\mathrm{C}$ for cobble (6.5-25.5 cm), P for pebble (2-6.5 cm), G for gravel $(4 \mathrm{~mm}-2 \mathrm{~cm})$, and $\mathrm{M}$ for mud (not distinguished from sand). If a substratum patch was comprised of two substrata in equal proportions, the patch was coded with the first letter indicating the substratum with larger grain size. If a patch comprised over 80 percent of a single substratum, the patch was coded with the same two letters (for example, MM). The substratum patches were eventually gathered in three habitat classes: flat soft, flat hard, and rugose hard (Cochrane, 2008).

Sessile invertebrates taller than $5 \mathrm{~cm}$ were identified and enumerated, as recommended by Riedl (1971) and Tissot and others (2006), because smaller individuals were difficult to see and identify on the images. Sponges and gorgonians, difficult to identify on video, were characterized based on their morphology and sometimes color (for example, branching sponge, encrusting sponge, branching red gorgonian). Encrusting ascidians and bryozoans, impossible to distinguish on video from encrusting sponges, were all gathered under the name encrusting sponge, while possible branching bryozoans were counted as branching sponges.

Motile invertebrates and fishes taller than $5 \mathrm{~cm}$ were identified to the lowest possible taxonomic level and enumerated. Some taxa were only identified to the family or genus level, because many species in these families/genera have overlapping morphological features and are difficult to distinguish without specimens to analyze. Fishes were mainly identified to broad morphotypes (for example, flatfish, rockfish), but individuals were recorded to the species level when recognizable without doubt (for example, lingcod, halibut). When the abundance of motile organisms was high, one to three additional viewings were needed to identify and enumerate all the individuals. 


\section{Substratum Patch Area and Species Density}

The video survey did not use a tracking system to produce camera-sled-position data that could be used to calculate the area covered by each substratum patch. Distance was calculated, instead, from the position of the boat at the sea surface. Although the sled was bouncing up and down with the swell at the ocean surface, resulting in some variability in the actual width of the camera view, for analysis the transect width was averaged to a fixed width $(1.15 \mathrm{~m})$ corresponding to the width of the view of the seafloor when the sled was neither too high nor low and organisms could be easily identified. The substratum patch area was calculated by multiplying the distance covered by the boat and the transect width. The density of each organism taxon per substratum patch was then calculated as the number of each organism taxon divided by the segment area.

\section{Statistical Analyses}

The statistical analyses were performed in three steps: (1) on the sessile and motile invertebrate data only to compare with results from Hemery and Henkel (2016); (2) on the fish data itself, despite the coarseness of the identifications, and (3) on both invertebrate and fish data together. The first step was to look at the variability of habitat types within a dive. For this purpose, all substratum patches of a same habitat type within a dive were merged into a bigger substratum patch if not separated by more than one minute between the end of one patch and the beginning of the following patch of a same type. This was done to avoid dealing with very short substratum patches of just a few seconds, which do not have ecological meaning at the scale of mega-invertebrate and fish habitats.

A matrix of Bray-Curtis similarities between substratum patches was calculated on logtransformed sessile- and motile-invertebrate density data, and a cluster analysis with group average linkage was performed using PRIMER 6th Edition (Clarke and Gorley, 2006). A lot of very small clusters paired similar substratum patches within a same dive, which prevented us from drawing a bigger picture. Because no obvious pattern was visible in this first cluster analysis (results not shown), the dataset was divided into two groups based on what was learned from Hemery and Henkel (2016): soft-sediment substratum patches (MM) and hard-flat substratum patches, which combined consolidated and unconsolidated rocks (MB, MC, MG, MP, BM, and RM). A cluster analysis was performed on each dataset to see if substratum patches were grouping by dive, by habitat type, by depth (six 100-m-depth bins from 0 to $600 \mathrm{~m}$ deep), or by any combination of these factors. The results of these cluster analyses showed that substratum patches of a same type from a same dive were mainly found in a same cluster (results not shown). So the following step was to pool together all substratum patches of a same habitat type within a dive, to have only one substratum patch of each habitat type per dive, and to merge back together soft-sediment and hard-flat substrate datasets. The final dataset consisted of 38 substratum patches from all 17 dives and both soft-sediment and hard-sediment types. Then a final cluster analysis was performed on this last dataset and a similarity of percentage (SIMPER) analysis was used to determine which taxa and their densities contributed to defining each group highlighted by the cluster analysis and the percent contribution of each defining taxon, as well as the average dissimilarity between groups.

The next step was to perform a cluster analysis, with group-average linkage on a matrix of BrayCurtis similarities between habitat types within stations based on the log-transformed fish densities, to determine fish biomes. A SIMPER analysis was then used to highlight the taxa defining each fish assemblage, as well as the percent of within-group similarity and between-groups dissimilarity. Then the memberships to the seven invertebrate biomes, as well as to the six depth bins, were plotted on the dendrogram. 
A last set of analyses was performed after combining invertebrate and fish dataset and computing a matrix of Bray-Curtis similarities between habitat types within stations based on the logtransformed invertebrate and fish densities. A cluster analysis with group average linkage was performed on this final matrix and the seven invertebrate biomes, as well as the seven fish biomes, were plotted on the dendrogram to help highlight the final biomes based on the whole benthic community. A SIMPER analysis was then used to determine the taxa defining each group, as well as the percent of within-group similarity and between-groups dissimilarity.

\section{Biomes}

\section{Diversity of Observations}

Seven different habitat types were recorded (mud mud, MM; mud boulder, MB; mud cobble, MC; mud gravel, MG; mud pebble, MP; boulder mud, BM; and ridge mud, RM; see table 3). Half of the video time covered areas of the MM habitat type (flat soft).

Table 3. Number of segments, total duration and percent of each type of habitat.

\begin{tabular}{llll}
\hline \multicolumn{1}{c}{ Habitat type } & No. of segments & Total duration & Percent \\
\hline Total & 1,401 & $11: 08: 50$ & 100 \\
Flat Soft (mud mud) & 550 & $06: 00: 23$ & 53.88 \\
Mixed & 223 & $01: 52: 03$ & 16.75 \\
$\quad$ mud boulder & 21 & $00: 04: 12$ & 0.63 \\
$\quad$ mud cobble & 130 & $01: 22: 25$ & 12.32 \\
$\quad$ mud gravel & 12 & $00: 04: 54$ & 0.73 \\
$\quad$ mud pebble & 55 & $00: 19: 51$ & 2.97 \\
$\quad$ boulder mud & 5 & $00: 00: 41$ & 0.10 \\
Rugose Hard (Ridge mud) & 1 & $00: 00: 14$ & 0.03 \\
Off Transect & 627 & $03: 16: 10$ & 29.33 \\
\hline
\end{tabular}

A total of 52,008 organisms belonging to 134 different taxa, and 46 other observations (for example, pieces of trash, seaweed chunks) have been recorded (table 4), but 7 percent of them were recorded during off transect segments, leaving a total of 48,274 usable observations. Echinoderms were by far the major group of organisms ( $\sim 5$ percent of the observations), followed by arthropods ( $\sim 5$ percent), cnidarians (5 percent), and fishes ( $\sim 5$ percent). Within echinoderms, a few species were dominant: the sea cucumber, Psolus squamatus, was the most abundant species ( $>15,000$ individuals), usually on rocky habitats; then the sea urchin, Strongylocentrotus (previously Allocentrotus) fragilis (8,500 ind.), usually on muddy habitats; the brittle star, Ophiomusium jolliensis (>6,500 ind.), only at the deepest station (dive 13) in a really dense carpet; and the "small orange brittle star" that might include several species, in rocky habitats. Among fishes, the main group was flatfishes ( $>750$ ind.), followed by thornyheads (>450 ind.) and rockfishes (>300 ind., among which a third was identified to six different species). Only 2,046 of the observed fishes were considered "on transect" and retained for the statistical analyses.

Fishing gear (crab pots, fishing lines/ropes) and trash (cans, glove, bucket, among others) were noticed on several dives (4, 7, 11, 12 for fishing gear; 6, 7, 12 for trash), but no deep and wide trench left on the seafloor by trawling activity was seen along any dive. Chunks of eelgrass (dives 10, 13, 15) 
and seaweed (dives 4,10) were seen as deep as $600 \mathrm{~m}$ (dive 13). A few patches looking like sponge spicule mats and bacterial mats were also noticed along dive 12.

Table 4. Counts and percent of total of the 52,054 sessile and motile organisms and other observations.

\begin{tabular}{|c|c|c|}
\hline Organism & Count & Percent \\
\hline PORIFERA & 1,583 & 3.04 \\
\hline Ball sponge & 83 & 0.16 \\
\hline Barrel sponge & 12 & 0.02 \\
\hline Branching sponge & 12 & 0.02 \\
\hline Clump sponge & 85 & 0.16 \\
\hline Encrusting sponge & 1,368 & 2.63 \\
\hline Foliose sponge & 4 & 0.01 \\
\hline Polymastia sp. & 1 & 0.00 \\
\hline Yellow chimney sponge & 18 & 0.03 \\
\hline CNIDARIA & 2,509 & 4.82 \\
\hline SEA ANEMONES & 1,223 & 2.35 \\
\hline Liponema brevicornis & 95 & 0.18 \\
\hline Metridium farcimen & 217 & 0.42 \\
\hline Urticina sp. & 1 & 0.00 \\
\hline Purple striated anemone & 505 & 0.97 \\
\hline Anemone sp1 & 43 & 0.08 \\
\hline Anemone sp2 & 21 & 0.04 \\
\hline Anemone sp3 & 6 & 0.01 \\
\hline Anemone sp4 & 20 & 0.04 \\
\hline Anemone sp5 & 35 & 0.07 \\
\hline Anemone sp6 & 27 & 0.05 \\
\hline Anemone sp7 & 17 & 0.03 \\
\hline Anemone sp8 & 20 & 0.04 \\
\hline Anemone sp9 & 20 & 0.04 \\
\hline Anemone sp10 & 3 & 0.01 \\
\hline Anemone sp11 & 22 & 0.04 \\
\hline Anemone sp12 & 51 & 0.10 \\
\hline Anemone sp13 & 4 & 0.01 \\
\hline Anemone sp14 & 2 & 0.00 \\
\hline Anemone sp15 & 11 & 0.02 \\
\hline Anemone sp16 & 6 & 0.01 \\
\hline Anemone sp17 & 1 & 0.00 \\
\hline Anemone sp18 & 1 & 0.00 \\
\hline Anemone sp19 & 1 & 0.00 \\
\hline Anemone sp20 & 1 & 0.00 \\
\hline Anemone sp22 & 41 & 0.08 \\
\hline Anemone sp23 & 1 & 0.00 \\
\hline Anemone sp24 & 12 & 0.02 \\
\hline
\end{tabular}




\begin{tabular}{|c|c|c|}
\hline Organism & Count & Percent \\
\hline Anemone sp25 & 6 & 0.01 \\
\hline Unidentified anemone & 33 & 0.06 \\
\hline SEA PENS / SEA WHIPS & 1,204 & 2.31 \\
\hline Long white sea whip & 62 & 0.12 \\
\hline Purple sea whip & 7 & 0.01 \\
\hline Short white sea whip & 92 & 0.18 \\
\hline Tiny white sea pen & 1,043 & 2.00 \\
\hline OTHER CNIDARIANS & 82 & 0.16 \\
\hline Heteropolypus ritteri & 31 & 0.06 \\
\hline Patch of hydroids & 4 & 0.01 \\
\hline Red branching gorgonian & 1 & 0.00 \\
\hline Tall hydroid branch & 46 & 0.09 \\
\hline CTENOPHORA & 8 & 0.02 \\
\hline Benthic ctenophore & 8 & 0.02 \\
\hline NEMERTEA & 11 & 0.02 \\
\hline Red ribbon worm & 7 & 0.01 \\
\hline Yellow ribbon worm & 4 & 0.01 \\
\hline ANNELIDA & 118 & 0.23 \\
\hline Bonellia sp. & 1 & 0.00 \\
\hline Feather-duster worm & 116 & 0.22 \\
\hline Scale worm & 1 & 0.00 \\
\hline BRACHIPODA & 1,250 & 2.40 \\
\hline Laqueus californianus & 1,250 & 2.40 \\
\hline MOLLUSCA & 1,864 & 3.58 \\
\hline GASTROPODS & 1,636 & 3.14 \\
\hline Dendronotid nudibranch & 2 & 0.00 \\
\hline Dorid nudibranch & 21 & 0.04 \\
\hline Grey snail & 307 & 0.59 \\
\hline Hairy snail & 348 & 0.67 \\
\hline Moon snail & 1 & 0.00 \\
\hline Neptunea sp. & 227 & 0.44 \\
\hline Purple snail & 3 & 0.01 \\
\hline White snail & 727 & 1.40 \\
\hline CEPHALOPODS & 227 & 0.44 \\
\hline Benthoctopus sp. & 14 & 0.03 \\
\hline Enteroctopus dofleini & 7 & 0.01 \\
\hline Octopus rubescens & 206 & 0.40 \\
\hline POLYPLACOPHORANS & 1 & 0.00 \\
\hline Chiton & 1 & 0.00 \\
\hline ARTHROPODA & 2,510 & 4.82 \\
\hline CRABS & 123 & 0.24 \\
\hline
\end{tabular}




\begin{tabular}{|c|c|c|}
\hline Organism & Count & Percent \\
\hline Cancer magister & 6 & 0.01 \\
\hline Chionoecetes tanneri & 4 & 0.01 \\
\hline Galatheid crab & 4 & 0.01 \\
\hline Hermit crab Paguridae & 76 & 0.15 \\
\hline Lopholithodes sp. & 25 & 0.05 \\
\hline Spider crab & 8 & 0.02 \\
\hline SHRIMPS & 2,387 & 4.59 \\
\hline Eualus macropthalmus & 620 & 1.19 \\
\hline Eualus sp. & 156 & 0.30 \\
\hline Pandalus platyceros & 205 & 0.39 \\
\hline Pink shrimp & 486 & 0.93 \\
\hline Small red shrimp & 920 & 1.77 \\
\hline ECHINODERMATA & 39,707 & 76.27 \\
\hline ASTEROIDS & 917 & 1.76 \\
\hline Astropecten californicus & 2 & 0.00 \\
\hline Ceramaster sp. & 3 & 0.01 \\
\hline Ctenodiscus crispatus & 48 & 0.09 \\
\hline Henricia sp. & 4 & 0.01 \\
\hline Heterozonias alternatus & 7 & 0.01 \\
\hline Hippasteria spinosa & 4 & 0.01 \\
\hline Hymenaster sp. & 4 & 0.01 \\
\hline Leptychaster sp. & 2 & 0.00 \\
\hline Luidia foliolata & 16 & 0.03 \\
\hline Mediaster aequalis & 4 & 0.01 \\
\hline Myxoderma platyacanthum & 642 & 1.23 \\
\hline Poraniopsis flexilis & 1 & 0.00 \\
\hline Pseudarchaster parelii alascencis & 20 & 0.04 \\
\hline Pteraster militaris & 9 & 0.02 \\
\hline Pycnopodia helianthoides & 1 & 0.00 \\
\hline Rathbunaster californicus & 74 & 0.14 \\
\hline Solaster sp. & 2 & 0.00 \\
\hline Stylasterias forreri & 58 & 0.11 \\
\hline Thrissacanthias penicillatus & 10 & 0.02 \\
\hline Unidentified sea star & 6 & 0.01 \\
\hline CRINOIDS & 2,756 & 5.29 \\
\hline Florometra serratissima & 2,085 & 4.00 \\
\hline Retiometra alascana & 671 & 1.29 \\
\hline ECHINOIDS & 8,500 & 16.33 \\
\hline Strongylocentrotus fragilis & 8,499 & 16.33 \\
\hline Heart sea urchin & 1 & 0.00 \\
\hline HOLOTHUROIDS & 15,159 & 29.12 \\
\hline Cucumaria sp. & 1 & 0.00 \\
\hline
\end{tabular}




\begin{tabular}{|c|c|c|}
\hline Organism & Count & Percent \\
\hline Parastichopus californicus & 4 & 0.01 \\
\hline Parastichopus leukothele & 22 & 0.04 \\
\hline Psolus chitonoides & 22 & 0.04 \\
\hline Psolus squamatus & 15,108 & 29.02 \\
\hline Unidentified sea cucumber & 2 & 0.00 \\
\hline OPHIUROIDS & 12,375 & 23.77 \\
\hline Asteronyx loveni & 3 & 0.01 \\
\hline Large orange brittle star & 380 & 0.73 \\
\hline Ophiomusium jolliensis & 6,512 & 12.51 \\
\hline Small orange brittle star & 5,403 & 10.38 \\
\hline Unidentified brittle star & 77 & 0.15 \\
\hline CHORDATA & 31 & 0.06 \\
\hline Stalked transparent tunicate & 24 & 0.05 \\
\hline Unstalked transparent tunicate & 7 & 0.01 \\
\hline VERTEBRATES (Fish) & 2,417 & 4.64 \\
\hline Catshark & 3 & 0.01 \\
\hline Darkblotched rockfish & 27 & 0.05 \\
\hline Eelpout & 277 & 0.53 \\
\hline Flatfish & 765 & 1.47 \\
\hline Greenstriped rockfish & 29 & 0.06 \\
\hline Grenadier & 3 & 0.01 \\
\hline Hagfish dark & 196 & 0.38 \\
\hline Hagfish light & 10 & 0.02 \\
\hline Halibut & 5 & 0.01 \\
\hline Lingcod & 10 & 0.02 \\
\hline Other fish & 22 & 0.04 \\
\hline Poacher & 289 & 0.56 \\
\hline Redbanded rockfish & 15 & 0.03 \\
\hline Rockfish, unidentified & 201 & 0.39 \\
\hline Rosethorn rockfish & 7 & 0.01 \\
\hline Sablefish & 14 & 0.03 \\
\hline Sharpchin rockfish & 26 & 0.05 \\
\hline Skate & 35 & 0.07 \\
\hline Snailfish & 3 & 0.01 \\
\hline Spotted ratfish & 4 & 0.01 \\
\hline Thornyhead & 475 & 0.91 \\
\hline Tiger rockfish & 1 & 0.00 \\
\hline OTHER OBSERVATIONS & 46 & 0.09 \\
\hline Bacterial mat & 4 & 0.01 \\
\hline Eelgrass chunk & 10 & 0.02 \\
\hline Egg case & 3 & 0.01 \\
\hline Fishing gear & 9 & 0.02 \\
\hline
\end{tabular}




\begin{tabular}{lll}
\hline \multicolumn{1}{c}{ Organism } & Count & Percent \\
\hline Seaweed chunk & 2 & 0.00 \\
Spicule mat & 1 & 0.00 \\
Trash & 12 & 0.02 \\
Unidentified other & 5 & 0.01 \\
\hline
\end{tabular}

\section{Results of Statistical Analyses on the Invertebrate Data}

The cluster analysis led to seven groups of substratum patches, based on the similarity of their invertebrate assemblages, which were called biomes A to G (fig. 16; table 5). One substratum patch (02MM) does not belong to any biome, because it was highly dissimilar to every other patch. This patch corresponds to the entire dive 02, which had about $8.5 \mathrm{~min}$ of "on transect" video time (and 4.5 min of "off transect" video time) and a total of only ten individuals belonging to nine invertebrate taxa (and 44 fishes) that were not unique to this dive. The addition of the fishes might change the output of the cluster analysis, but as far as the invertebrates were concerned, the patch 02MM did not seem to be representative of the study area and was not considered further in the following discussion.

Table 5. Description of the seven invertebrate biomes and the associated dives.

\begin{tabular}{lll}
$\begin{array}{c}\text { Invertebrate } \\
\text { biome }\end{array}$ & \multicolumn{1}{c}{ Habitat type and depth } & \multicolumn{1}{c}{ Dive No. } \\
\hline A & Hard flat sediments at $98 \mathrm{~m}$ & 17 \\
$\mathrm{~B}$ & Hard flat sediments at 230-270 m & $04,06,11$ \\
$\mathrm{C}$ & Hard flat sediments at 300-370 m & 07,12 \\
$\mathrm{D}$ & Soft flat sediments at 98-230 m & $06,15,17$ \\
$\mathrm{E}$ & Soft flat sediments at 250-310 m & $03,11,16$ \\
$\mathrm{~F}$ & Soft flat sediments at 330-465 m & $03,07,14$ \\
$\mathrm{G}$ & Soft flat sediments at 470-600 m & $01,05,08,09,10,13$ \\
\hline
\end{tabular}

Biomes A, B, and C consisted mainly of hard flat (100 percent of biome A, 58 percent of biome $\mathrm{B}$, and 86 percent of biome $\mathrm{C}$ ) substratum patches (fig. 16) from the shallowest dive 17 (98 $\mathrm{m}$ ) for biome A, from dives between $230 \mathrm{~m}$ and $270 \mathrm{~m}$ (dives 04, 06, and 11) for biome B, and from dives between $300 \mathrm{~m}$ and $370 \mathrm{~m}$ (dives 07 and 12) for biome $C$ (table 5). These three biomes showed from 36 percent to 45 percent of within-group similarity (table 6) and between 91 percent and almost 100 percent of between-groups dissimilarity. Biome A was characterized by a high density of the sea anemone, Metridium farcimen (table 7); biome B was characterized by a high density of the feather star, Florometra serratissima, as well as by the presence of the spot prawn, Pandalus platyceros, and the unidentified small red shrimp; biome $\mathrm{C}$ was characterized by a high density of the white creeping pedal sea cucumber, Psolus squamatus, as well as by the presence of unidentified small orange brittle stars and large orange brittle stars, the lantern shell, Laqueus californianus, unidentified small red shrimps, white snails and encrusting sponge in more-or-less high density. 


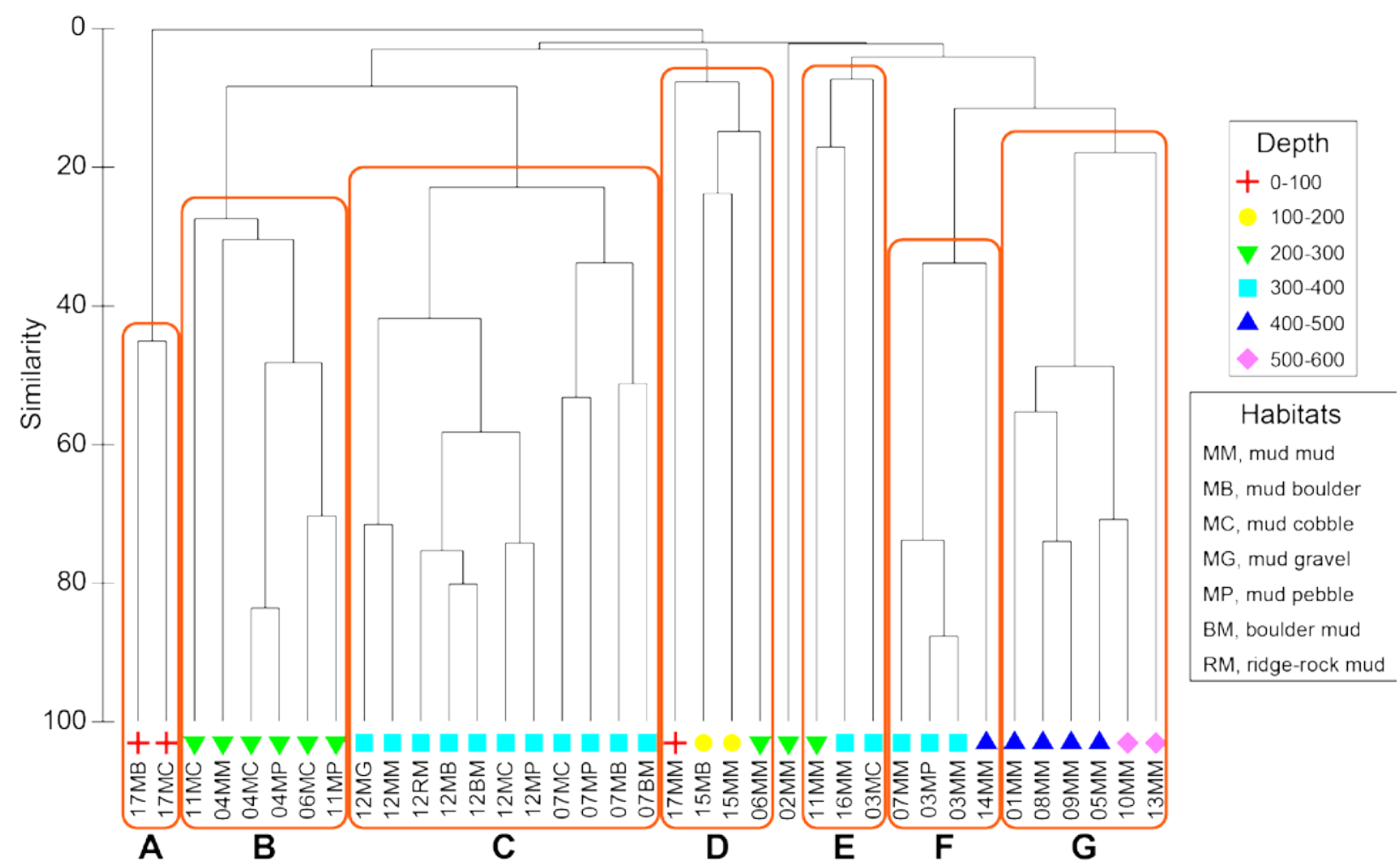

Figure 16. Cluster analysis on the invertebrate data, highlighting the seven biomes identified in this study. Symbols indicate depth bin and labels are the dive number and substratum type.

Table 6. Percent of similarity within an invertebrate biome (diagonal, in italic) and of dissimilarity in between biomes (lower matrix) from the SIMPER analysis.

\begin{tabular}{l|rrrrrrr}
\hline Biome & A & B & C & D & E & F & G \\
\hline A & 45.14 & & & & & & \\
B & 99.93 & 40.40 & & & & & \\
C & 99.98 & 91.65 & 36.84 & & & & \\
D & 99.06 & 97.58 & 96.68 & 12.77 & & & \\
E & 100.00 & 98.56 & 99.33 & 96.34 & 10.57 & & \\
F & 100.00 & 98.80 & 97.57 & 99.47 & 96.35 & 56.17 & \\
G & 100.00 & 98.98 & 95.70 & 99.49 & 95.63 & 88.50 & 42.51 \\
\hline
\end{tabular}

Biome D, E, F, and G consisted mainly of flat soft sediment substratum patches (fig. 16) from dives between $98 \mathrm{~m}$ and $230 \mathrm{~m}$ (dives 06,15 , and 17) for biome $\mathrm{D}$, from the depth range 250-310 $\mathrm{m}$ (dives 03, 11, and 16) for biome E, from $330 \mathrm{~m}$ to $465 \mathrm{~m}$ deep (dives 03, 07, and 14) for biome F, and from the deepest dives (470-600 m, dives 01, 05, 08, 09, 10, and 13) for biome $\mathrm{G}$ (table 5). These four biomes showed from 10 percent to 56 percent of within-group similarity (table 6) and between 88 percent and 100 percent of between-groups dissimilarity. Biome D was characterized by the presence of the red octopus, Octopus rubescens, and the Pink shrimp (table 7); biome E was characterized by the presence of the red octopus and the purple striated anemone; biome $\mathrm{F}$ was characterized by a high density of the pink sea urchin, Strongylocentrotus fragilis; and biome G was characterized by the presence of the purple striated anemone, unidentified gray snails, hairy snails and white snails, the sea star, Myxoderma platyacanthum, and the shrimp, Eualus macropthalmus. 
Table 7. Invertebrate assemblage characteristics for each biome based on the SIMPER analysis.

[\% Sim, percent of within-group similarity; Av den, average density of the taxon within the group (individuals $/ \mathrm{m}^{2}$ ) after logtransformation; Cum \%, cumulative percent of contribution of the taxon to within-group similarity]

\begin{tabular}{|c|c|c|c|c|}
\hline $\begin{array}{c}\text { Invertebrate } \\
\text { biome }\end{array}$ & \% Sim & Taxa & Av den & Cum \% \\
\hline $\mathrm{A}$ & 45.14 & Metridium farcimen & 1.72 & 100.00 \\
\hline \multirow{3}{*}{ B } & \multirow{3}{*}{40.4} & Florometra serratissima & 1.05 & 82.60 \\
\hline & & Pandalus platyceros & 0.22 & 86.95 \\
\hline & & Small red shrimp & 0.07 & 90.02 \\
\hline \multirow{7}{*}{$\mathrm{C}$} & \multirow{7}{*}{36.84} & Psolus squamatus & 1.45 & 47.13 \\
\hline & & Small orange brittle star & 0.80 & 62.73 \\
\hline & & Encrusting sponge & 0.59 & 75.67 \\
\hline & & Laqueus californianus & 0.55 & 81.05 \\
\hline & & Small red shrimp & 0.18 & 86.21 \\
\hline & & White snail & 0.14 & 88.72 \\
\hline & & Large orange brittle star & 0.21 & 91.06 \\
\hline \multirow{2}{*}{$\mathrm{D}$} & \multirow{2}{*}{12.77} & Octopus rubescens & 0.08 & 48.28 \\
\hline & & Pink shrimp & 0.17 & 96.30 \\
\hline \multirow{2}{*}{ E } & \multirow{2}{*}{10.57} & Octopus rubescens & 0.01 & 48.52 \\
\hline & & Purple striated anemone & 0.01 & 94.58 \\
\hline $\mathrm{F}$ & 56.17 & Strongylocentrotus fragilis & 0.92 & 92.48 \\
\hline \multirow{6}{*}{ G } & \multirow{6}{*}{42.51} & Purple striated anemone & 0.11 & 23.55 \\
\hline & & Hairy snail & 0.12 & 40.80 \\
\hline & & Myxoderma platyacanthum & 0.14 & 55.53 \\
\hline & & White snail & 0.12 & 69.21 \\
\hline & & Eualus macropthalmus & 0.09 & 81.74 \\
\hline & & Grey snail & 0.06 & 93.55 \\
\hline
\end{tabular}

\section{Results of Statistical Analyses on the Fish Data}

The cluster analysis on the fish assemblages (fig. 17) led to seven groups (a-g; fig. 17A; table 8), but three of them were composed of less than two samples and will not be further discussed here.

Biomes $\mathrm{f}$ and g consisted mainly of flat soft sediment substratum patches, between 170-315 m deep for biome $\mathrm{f}$ and 300-600 $\mathrm{m}$ for biome g, with the exception of the shallowest substratum patch (dive 17) that clustered within this group (fig. 17B). Similar to the invertebrates, patch 03MP clustered with soft sediment patches. These two fish assemblages showed respectively 70 percent and 65 percent of withingroup similarity and 59 percent of between-group dissimilarity (table 9), mainly owing to a much higher abundance of eelpouts in biome g (table 10). On the other hand, biomes c and e mainly consisted of hard flat substratum patches without significant distinction among depths between 100-300 m in biome c and 200-400 $\mathrm{m}$ in biome e (fig. 17B). Similar to the invertebrates, patches 04MM and 12MM clustered with hard flat substratum patches. Biome e showed 57 percent of within-group dissimilarity (table 9) and was mainly comprised of thornyheads, unidentified flatfishes, and poachers (table 10 
Table 8. Description of the fish biomes, and the dives belonging to each of them.

\begin{tabular}{lll}
\hline $\begin{array}{c}\text { Fish } \\
\text { biome }\end{array}$ & \multicolumn{1}{c}{ Habitat type and depth } & \multicolumn{1}{c}{ Dive No. } \\
\hline a & Hard flat sediments at $340-360 \mathrm{~m}$ & 07 \\
b & Hard flat sediments at $310-330 \mathrm{~m}$ & 03 \\
c & Hard flat sediments at $170-230 \mathrm{~m}$ & 06,15 \\
d & Hard flat sediments at $170 \mathrm{~m}$ & 15 \\
e & Hard flat sediments at $250-370 \mathrm{~m}$ & $04,07,11,12$ \\
$\mathrm{f}$ & Soft flat sediments at $170-315 \mathrm{~m}$ & $02,06,11,15,16$ \\
& & $01,03,05,07,08,09,10,13,14$, \\
g & Soft flat sediments at $98-600 \mathrm{~m}$ & 17 \\
\hline
\end{tabular}

The invertebrate biomes were not fully recovered with the fish data. Invertebrate biome A did not host any fish. Invertebrate biome B was split among two fish biomes: fish biome c (sediment patch 06MC) and fish biome d (sediment patch 15MB). Invertebrate biome B patches, from dives 04 and 11, formed fish biome e alongside with patches from invertebrate biome $\mathrm{C}$ (excluding 07MB which solely formed fish biome a (fig. 18C). Most of the rockfishes observed during the survey were recorded during patch 06MC: 14 greenstriped, 10 redbanded, 2 rosethorn, 9 sharpchin, 1 tiger, and 142 non-identified rockfishes, but not a single thornyhead. Other patches of fish biome b (dives 04 and 11) did not host more than 8 individual rockfishes but up to 49 thornyheads. The SIMPER analysis showed 84 percent of dissimilarity between these two fish assemblages, with the species listed above counting for over 70 percent of the differences (table 9). The four samples of invertebrate biome D were scattered among three fish biomes (c, f, and g) and the three samples of invertebrate biome $\mathrm{E}$ were found in two fish biomes (b and f). Invertebrate biomes $\mathrm{F}$ and $\mathrm{G}$ formed a single fish assemblage, biome g (fig. 18C).

Table 9. Percent of similarity within a fish biome (diagonal, in italic) and of dissimilarity between biomes (lower matrix) from the SIMPER analysis.

\begin{tabular}{l|llrrrrr}
\hline Biome & \multicolumn{1}{|c}{$\mathbf{a}$} & $\mathbf{b}$ & $\mathbf{c}$ & $\mathbf{d}$ & $\mathbf{e}$ & $\mathbf{f}$ & $\mathbf{g}$ \\
\hline $\mathrm{a}$ & - & & & & & & \\
$\mathrm{b}$ & 92.45 & - & & & & & \\
$\mathrm{c}$ & 86.18 & 100 & 35.22 & & & & \\
d & 100 & 100 & 86.88 & - & & & \\
e & 84.25 & 78.35 & 84.34 & 80.34 & 56.58 & & \\
$\mathrm{f}$ & 97.71 & 88.75 & 76.33 & 71.10 & 60.02 & 69.99 & \\
g & 97.65 & 87.55 & 86.55 & 86.60 & 71.20 & 58.65 & 65.41 \\
\hline
\end{tabular}



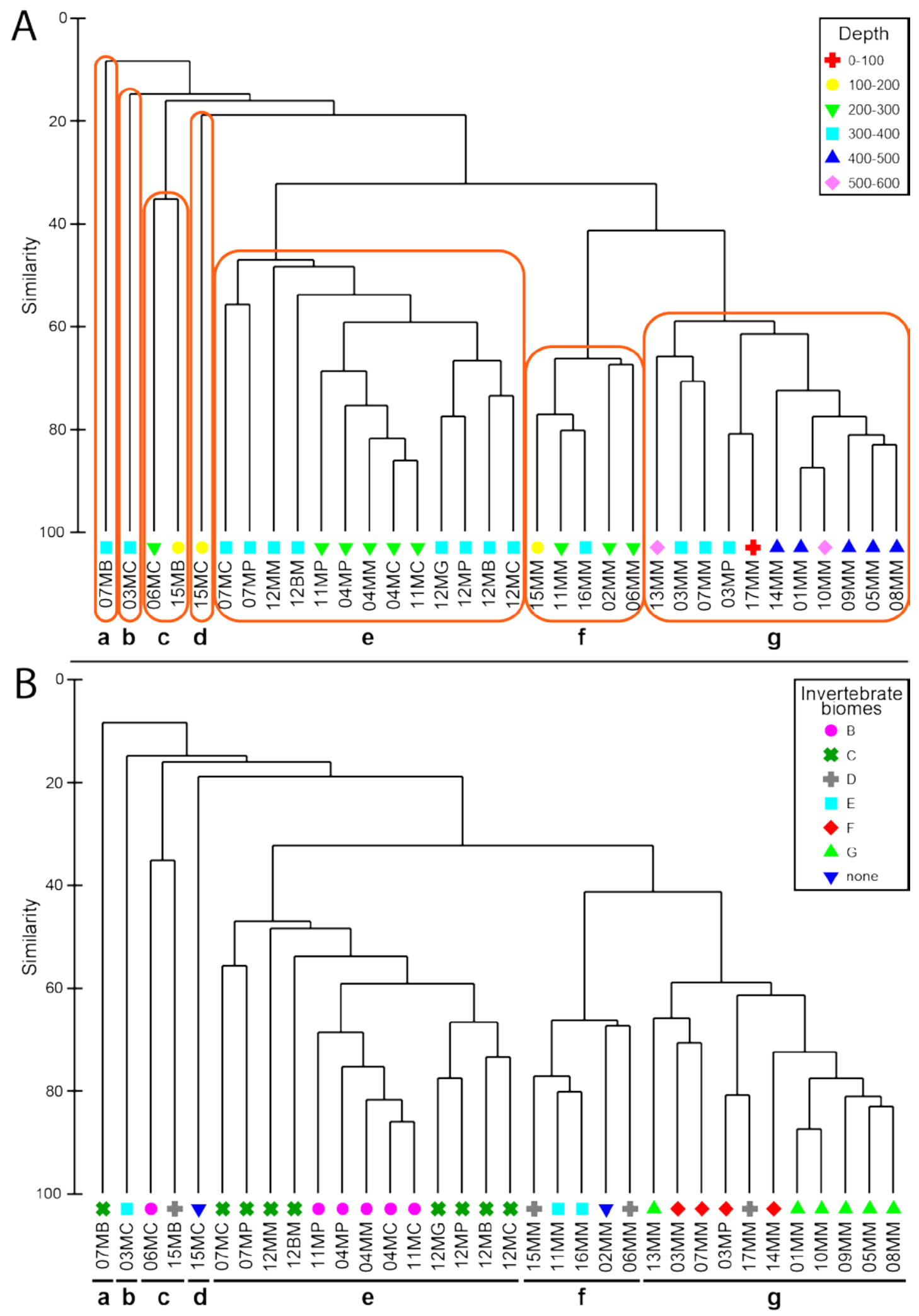

Figure 17. Cluster analysis on the fish data, highlighting the fish biomes and their distribution along the depth $(A)$, and the distribution of the invertebrate biomes within these groups $(B)$. Symbols indicate either depth bins or invertebrate biomes, and labels are the dive number and substratum type. 
Table 10. Assemblage characteristics for the four major fish biomes based on the SIMPER analysis.

[\% Sim, percent of within-group similarity; Av den, average density of the taxon within the group (individuals $/ \mathrm{m}^{2}$ ) after logtransformation; Cum \%, cumulative percent of contribution of the taxon to within-group similarity]

\begin{tabular}{lllll}
\hline Fish biome & \% Sim & \multicolumn{1}{c}{ Taxa } & Av den & Cum \% \\
\hline \multirow{4}{*}{$\mathrm{c}$} & & Rockfish & 0.36 & 37.24 \\
& \multirow{2}{*}{35.22} & Flatfish & 0.07 & 62.42 \\
& & Sharpchin & 0.10 & 87.24 \\
& & Greenstriped & 0.06 & 100 \\
\hline \multirow{2}{*}{$\mathrm{e}$} & \multirow{2}{*}{56.58} & Thornyhead & 0.09 & 38.79 \\
& & Flatfish & 0.08 & 68.69 \\
& & Poacher & 0.05 & 91.77 \\
\hline $\mathrm{f}$ & 69.99 & Flatfish & 0.09 & 90.60 \\
\hline \multirow{3}{*}{$\mathrm{g}$} & & Eelpout & 0.06 & 45.80 \\
& \multirow{2}{*}{65.41} & Flatfish & 0.04 & 86.04 \\
& & Thornyhead & 0.01 & 92.15 \\
\hline
\end{tabular}

\section{Results of Statistical Analyses on the Combined Fish and Invertebrate Data}

The combined fish and invertebrate cluster analysis arranged the dataset into seven groups, hereafter called final biomes 1 to 7 (fig. 18A). One of them (final biome 5) consisted of a single substratum patch (MC at dive 03) and a second one (final biome 1) consisted of two substratum patches (MB and MC at dive 17). Final biomes 1, 2, 3, 6, and 7 perfectly matched the invertebrate biomes A, B, C, F, and G, respectively (fig. 18B), whereas final biome 4 consisted of substratum patches classified as invertebrate biomes $\mathrm{D}$ and $\mathrm{E}$ and two patches that were not attributed to any invertebrate biome. Final biome 5 is based on a single video transect across the slump scar (figs. 3,14 ) and consisted of a single patch belonging to invertebrate biome $\mathrm{E}$ and fish biome $\mathrm{b}$. The fish biomes were more scattered throughout the final biomes, with fish biome e found within both final biomes 2 and 3 and fish biome $g$ found within both final biomes 6 and 7 (fig. 18C). Final biome 4 consisted of the entire fish biomes d and $\mathrm{f}$, as well as one patch of both fish biomes $\mathrm{c}$ and $\mathrm{g}$. The two substratum patches making up final biome 1 did not have any record of fish. Final biome 2 also comprised a patch from fish biome c (06MC), and final biome 3 comprised the single-patch fish biome a (07MB). Similar to invertebrate biomes, final biomes were mainly divided by sediment type and depth, with three biomes of hard flat substrates at $\sim 100 \mathrm{~m}, 230-270 \mathrm{~m}$, and 300-370 m deep, and three biomes of soft sediments at 100-315 m, 330-465 m, and 470-600 m deep (table 11).

Table 11. Description of the final biomes, and the dives belonging to each of them.

\begin{tabular}{lll}
\hline $\begin{array}{c}\text { Final } \\
\text { biome }\end{array}$ & \multicolumn{1}{c}{ Substrate type and depth } & \multicolumn{1}{c}{ Dive No. } \\
\hline 1 & Hard flat substrate at $98 \mathrm{~m}$ & 17 \\
2 & Hard flat substrate at $230-270 \mathrm{~m}$ & $04,06,11$ \\
3 & Hard flat substrate at $300-370 \mathrm{~m}$ & 07,12 \\
4 & Soft flat substrate at $98-315 \mathrm{~m}$ & $02,06,11,15,16,17$ \\
5 & Hard flat substrate at $310-330 \mathrm{~m}$ & 03 \\
6 & Soft flat substrate at $330-465 \mathrm{~m}$ & $03,07,14$ \\
7 & Soft flat substrate at $470-600 \mathrm{~m}$ & $01,05,08,09,10,13$ \\
\hline
\end{tabular}



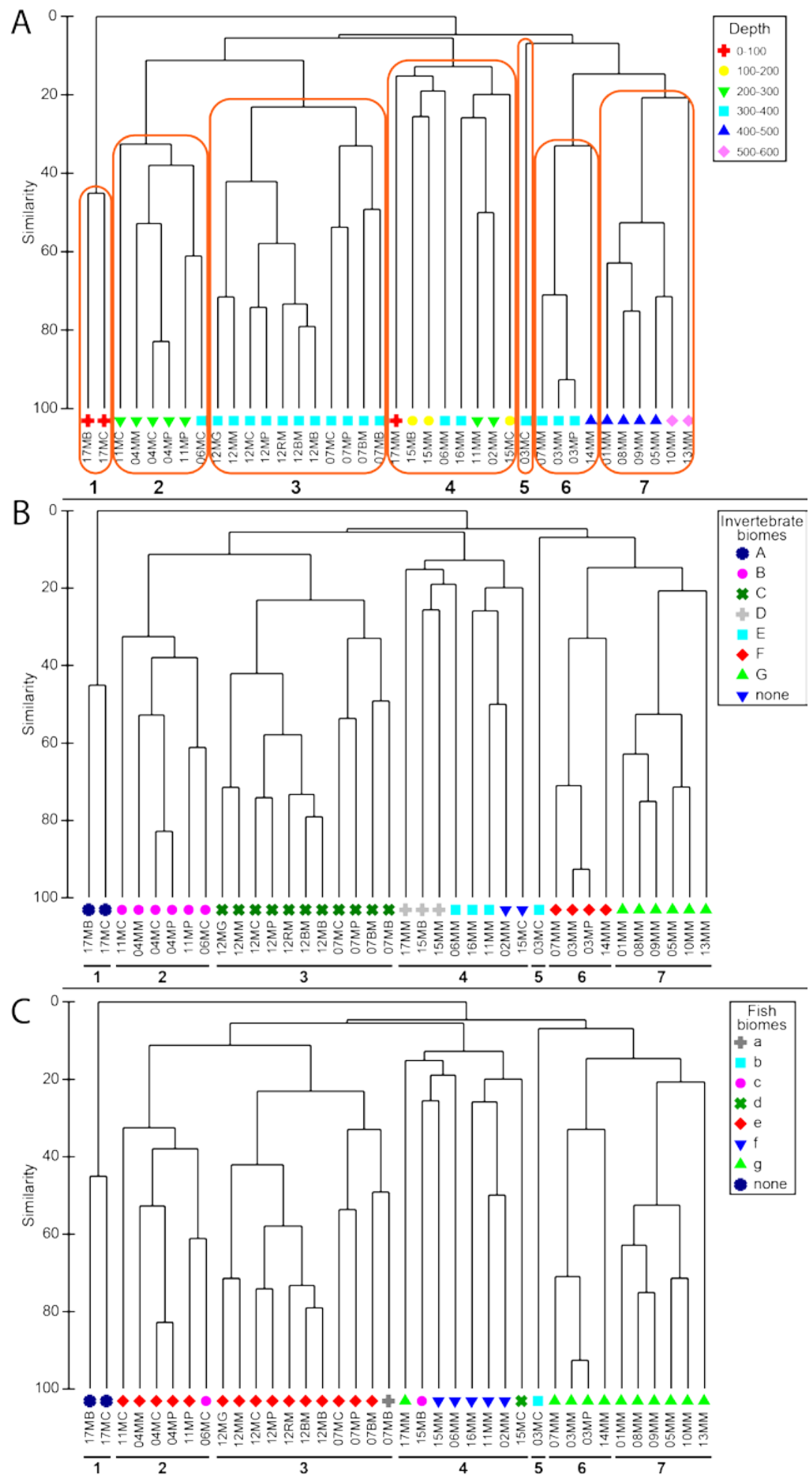

Figure 18. Cluster analysis on the combined fish and invertebrate data, highlighting the seven final biomes and their distribution along the depth $(A)$, the distribution of the seven invertebrate biomes within these groups $(B)$, and the distribution of the seven fish biomes within these groups $(C)$. Symbols indicate either depth bins, invertebrate biomes, or fish biomes; labels are the dive number and substratum type. 
Hard flat substrate final biomes (1, 2, and 3) showed between 37-45 percent of within-group similarity while soft sediment final biomes (4, 6, and 7) showed between 17-56 percent of within-group similarity (table 12). Most of the between-group dissimilarity was very high (table 12), with an average of 95.7 percent. The lowest dissimilarities were observed between soft sediment final biomes 6 and 7 (85.25 percent) and hard flat substrate final biomes 2 and 3 (88.69 percent).

Table 12. Percent of similarity within a biome (diagonal, in italic) and of dissimilarity in between biomes (lower matrix) from the SIMPER analysis.

\begin{tabular}{l|rrrrrrr}
\hline $\begin{array}{c}\text { Final } \\
\text { biome }\end{array}$ & $\mathbf{1}$ & $\mathbf{2}$ & $\mathbf{3}$ & $\mathbf{4}$ & $\mathbf{5}$ & $\mathbf{6}$ & $\mathbf{7}$ \\
\hline 1 & 45.14 & & & & & & \\
2 & 99.94 & 42.73 & & & & & \\
3 & 99.98 & 88.69 & 36.83 & & & & \\
4 & 99.50 & 90.83 & 96.34 & 17.06 & & & \\
5 & 100 & 97.50 & 98.12 & 96.15 & - & & \\
6 & 100 & 95.56 & 96.37 & 94.90 & 94.14 & 55.65 & \\
7 & 100 & 96.19 & 94.36 & 93.88 & 92.30 & 85.25 & 46.16 \\
\hline
\end{tabular}

The shallowest hard flat substrate final biome (1) was characterized by a high abundance of the plumose anemone, Metridium farcimen (table 13), in addition to two other sea anemone species and the sea star, Mediaster aequalis, in much lower abundances. The habitat of this biome was made of patches of big cobbles and small boulders entirely covered by the plumose anemones. Unlike the first biome, the habitat of final biome 2 was mainly made of pebbles and small cobbles scattered on a coarse soft sediment floor. The organisms characterizing this biome were the feather star, Florometra serratissima, in very dense aggregations (almost every rock was topped with one or more crinoids), flatfishes, thornyheads, poachers, the Pacific spot prawn, Pandalus platycero,s and some unidentified small red shrimps. The deepest hard flat substrate final biome (3) was characterized by the white creeping pedal sea cucumber, Psolus squamatu,s in extremely high numbers, unidentified large and small orange brittle stars, encrusting sponges, the lantern shell, Laqueus californianus, unidentified small red shrimps and white snails, thornyheads and the feather star, Retiometra alascana. The habitat of this biome was made of either small rocks (pebbles, gravels, cobbles) scattered in mud or bigger rocks (boulders and small ridge rocks) surrounded by soft sediments or covered by a veneer of mud.

The shallowest soft sediment final biome (4) was characterized by the presence of flatfishes of probably several species, many red octopus, Octopus rubescens, often seen curled up in holes in the mud, and aggregations of pink shrimps (table 13). An identification of the flatfishes to the species level may have led to a split of this cluster into two or more clusters with a narrower depth range. The middepth soft sediment final biome (6) was characterized by very high numbers of the fragile pink sea urchin, Strongylocentrotus fragilis, small sea anemones nicknamed purple striated anemones that were seen on snails, hermit crabs or isolated pebbles, and flatfishes of probably several species. The deepest soft sediment final biome (7) was characterized by a higher abundance of purple striated anemones, by different types of snails, the sea star, Myxoderma platyacanthum, the shrimp, Eualus macropthalmus, eelpouts, and flatfishes of probably several species. The deepest dive (13) was also characterized by a very dense mat of the brittle star, Ophiomusium jolliensis, not seen elsewhere, which explains its position of outlier in this cluster. 
Table 13. Assemblage characteristics for each final biome based on the SIMPER analysis. Biome 5 was made of a single patch and is not shown is this table.

[\% Sim, percent of within-group similarity; Av den, average density of the taxon within the group (individuals $/ \mathrm{m}^{2}$ ) after $\log$ transformation; Cum \%, cumulative percent of contribution of the taxon to within-group similarity]

\begin{tabular}{|c|c|c|c|c|}
\hline Final biome & $\% \operatorname{Sim}$ & Taxa & Av den & Cum \% \\
\hline 1 & 45.14 & Metridium farcimen & 1.72 & 100.00 \\
\hline \multirow{6}{*}{2} & \multirow{6}{*}{42.73} & Florometra serratissima & 1.05 & 63.54 \\
\hline & & Flatfish & 0.11 & 74.60 \\
\hline & & Thornyhead & 0.08 & 81.96 \\
\hline & & Poacher & 0.05 & 86.49 \\
\hline & & Pandalus platyceros & 0.22 & 89.95 \\
\hline & & Small red shrimp & 0.07 & 92.38 \\
\hline \multirow{9}{*}{3} & \multirow{9}{*}{36.83} & Psolus squamatus & 1.44 & 44.68 \\
\hline & & Small orange brittle star & 0.80 & 59.52 \\
\hline & & Encrusting sponge & 0.59 & 71.82 \\
\hline & & Laqueus californianus & 0.55 & 76.90 \\
\hline & & Small red shrimp & 0.18 & 81.77 \\
\hline & & White snail & 0.14 & 84.13 \\
\hline & & Large orange brittle star & 0.21 & 86.40 \\
\hline & & Thornyhead & 0.07 & 88.63 \\
\hline & & Retiometra alascana & 0.12 & 90.29 \\
\hline \multirow{3}{*}{4} & \multirow{3}{*}{17.06} & Flatfish & 0.11 & 70.03 \\
\hline & & Octopus rubescens & 0.05 & 84.20 \\
\hline & & Pink shrimp & 0.08 & 90.60 \\
\hline \multirow{3}{*}{6} & \multirow{3}{*}{55.65} & Strongylocentrotus fragilis & 0.96 & 87.10 \\
\hline & & Purple striated anemone & 0.03 & 89.86 \\
\hline & & Flatfish & 0.03 & 92.24 \\
\hline \multirow{8}{*}{7} & \multirow{8}{*}{46.16} & Purple striated anemone & 0.12 & 18.65 \\
\hline & & Hairy snail & 0.12 & 32.50 \\
\hline & & Myxoderma platyacanthum & 0.15 & 46.25 \\
\hline & & White snail & 0.13 & 57.41 \\
\hline & & Eualus macropthalmus & 0.09 & 67.48 \\
\hline & & Grey snail & 0.07 & 77.11 \\
\hline & & Eelpout & 0.05 & 86.11 \\
\hline & & Flatfish & 0.03 & 91.54 \\
\hline
\end{tabular}

\section{Biotopes}

The three sets of cluster analyses here performed showed that both fishes and invertebrates are necessary to highlight biomes of benthic organisms on the Oregon middle and outer continental shelf, but also that invertebrates alone represent most of the structure of the whole benthic community into different assemblages, even if not all invertebrate taxa were identified to the species level. The number of fish taxa listed in the current study is much lower than the actual diversity of fish species on the Oregon continental shelf, due to a lack of fish identification skills. For instance, Hixon and Tissot 
(2007) recognized 35 fish taxa along six video transects near Coquille Bank, about $30 \mathrm{~km}$ south of the present study site, among them seven species of flatfish, three species of skates and seven species of rockfish (five were shared with the present study). Because of the depth range of the present study, most of the thornyheads encountered were probably the shortspine thornyhead, Sebastolobus alascanus, which was the only thornyhead species reported in Hixon and Tissot (2007), as the longspine thornyhead, S. altiveli,s is more common below $500 \mathrm{~m}$ deep, even if recorded as shallow as $163 \mathrm{~m}$ (Butler and others, 2012). In addition, not all hagfishes may have been enumerated due to their burrowing way of life, even if many of them were spotted in their burrows in mud or underneath rocks and counted. The lighter-colored individuals were probably of the shallower species, Eptatretus stoutii, or Pacific hagfish, while the darker-colored individuals were most likely the deeper-dwelling E. deani or black hagfish (W. Wakefield, written commun., 2015).

The partition of the benthic communities by depth range and composition of the sediment is not unusual (Hemery and Henkel, 2016, for an Oregon example). A striking difference with previous benthic-assemblage studies on the west coast continental shelf of the United States (for example, Hemery and Henkel, 2016; Tissot and others, 2006) was the total absence of the basket star, Gorgonocephalus eucnemi,s at the present site. This species has been recorded in high abundance on low-relief hard flat substrates and high-relief rocks, for instance at Bandon-Arago (20 km southeast of the present study site; Henkel and others, 2014). On the other hand, another structure-forming echinoderm species, the feather star, Florometra serratissima (crinoid), was found in high abundance and was characteristic of the final biome 2. Hundreds of them formed an association with numerous Pacific spot prawns, flatfishes, thornyheads, and rockfishes of different species, gathered in a habitat made of large but shallow pockmarks filled with scattered pebbles or cobbles along the 230-270 m isobaths. Almost every rock was capped with one or more crinoids, and rockfishes, thornyheads, and Pacific spot prawns seemed to aggregate around the crinoids or even underneath their crown of arms. This feather star is usually associated with big cobble and boulder habitats on the Oregon continental shelf (Hixon and others, 1991; Strom, 2006) but has been reported in high densities on smaller rock habitats in the vicinity of Vancouver Island (Clark and Clark, 1967). The crinoids are, thus, thought to provide an additional layer of habitat for the fishes in this rather flat environment; this point is further developed in the Pockmark Habitat section.

Another particularity of the study site off Coos Bay was its great depth range (98-608 m deep), which allowed the encounter of shallow subtidal species (for example, the sea stars, Mediaster aequalis and Pycnopodia helianthoides, or the red octopus, Octopus rubescens) but also of deep-sea species (for example, the sea star, Heterozonias alternatus, or the tanner crab, Chionoecetes tanneri). Several deepsea species of fish were observed on the videos. The sablefish, Anoplopoma fimbria, was observed at dives from 300-600 m deep but was the most abundant (9 out of 14 observations) between 300-360 m (dives 3 and 7). This species is common in the eastern Pacific, usually found in the 175-1,450 m depth range (Froese and Pauly, 2015). Two of the three snailfishes were blacktail snailfishes, Careproctus melanurus, one at dive 11 ( $250 \mathrm{~m}$ deep) and the second at dive 13 ( $\sim 600 \mathrm{~m}$ deep). This is a species usually common between 500-700 m, but some records exist as shallow as $90 \mathrm{~m}$ deep (Froese and Pauly, 2015). The third snailfish, along dive 13, could not be clearly identified to the species level. The three grenadiers (Albatrossia pectoralis) were recorded during the two dives deeper than $500 \mathrm{~m}$ (dives 10 and 13), which fits in the upper range of the species distribution, usually more common below $700 \mathrm{~m}$ deep (Froese and Pauly, 2015). Finally, the three catsharks (probably brown catsharks, Apristurus brunneus) were recorded only during dive 13, the deepest dive of the study. This shark has been occasionally observed from 33-1,298 $\mathrm{m}$ depth on the outer continental shelf and upper slope of the eastern Pacific, but little is known about the species (Froese and Pauly, 2015). 
The study site was also particular in its lack of big rocky outcrops. The hard substrate areas were mainly constituted of unconsolidated rocks scattered among soft sediments, even at the ridge documented in the southwestern part of the site (fig. 14), which was mainly made of cobbles and boulders mixed in soft sediments. Only 0.3 percent of all the video time documented a rugose hard (ridge mud) habitat type, observed along dive 12. Therefore, the benthic assemblages present on this ridge were more similar to assemblages found on unconsolidated rocky habitats than consolidated rocky habitats in Hemery and Henkel (2016): sea anemones, encrusting sponges, white creeping pedal sea cucumbers and crack-dwelling brittle stars. The only structure-forming invertebrates observed on the ridge were crinoids, although Retiometra alascana was chiefly observed in cracks between rocks and only Florometra serratissima was seen on top of rocks, 15 yellow chimney sponges in the mud-cobble habitat, 9 barrel sponges of relatively small size in mud-gravel and mud-cobble habitats, and a single small red branching gorgonian in the mud-pebble habitat. The poverty of rockfishes (18) and lingcods (1) on the ridge is likely explained by the quasi absence of structure-forming invertebrates, which flatfishes (72), hagfishes (92) and poacher (154) do not especially look for.

\section{Biotope Map}

A biotope raster (fig. 19) was generated for the final combined fish and invertebrate biomes using the seafloor character class and depth ranges shown in table 11. Final biome 1 is not represented in the raster because the Solmar Hydro Inc. survey dataset provided to us did not include the shallowwater area mapped by Solmar Hydro Inc. Not all the combinations of seafloor character class and depth are captured by a biome, for example the video survey did not produce many hard-rugose observations so hard rugose portions of the ridges in the southwestern map area are not assigned a biome. Hard substrate areas shallower than $200 \mathrm{~m}$ depth and hard rugose substrate areas deeper than $270 \mathrm{~m}$ were also not assigned a biome. Hard rugose substrate in the linear area of pockmarks at depths of 230 to $270 \mathrm{~m}$ were assigned to biome 2 on the assumption that hard substrate within a pockmark would support the same biota regardless of the rugosity. 


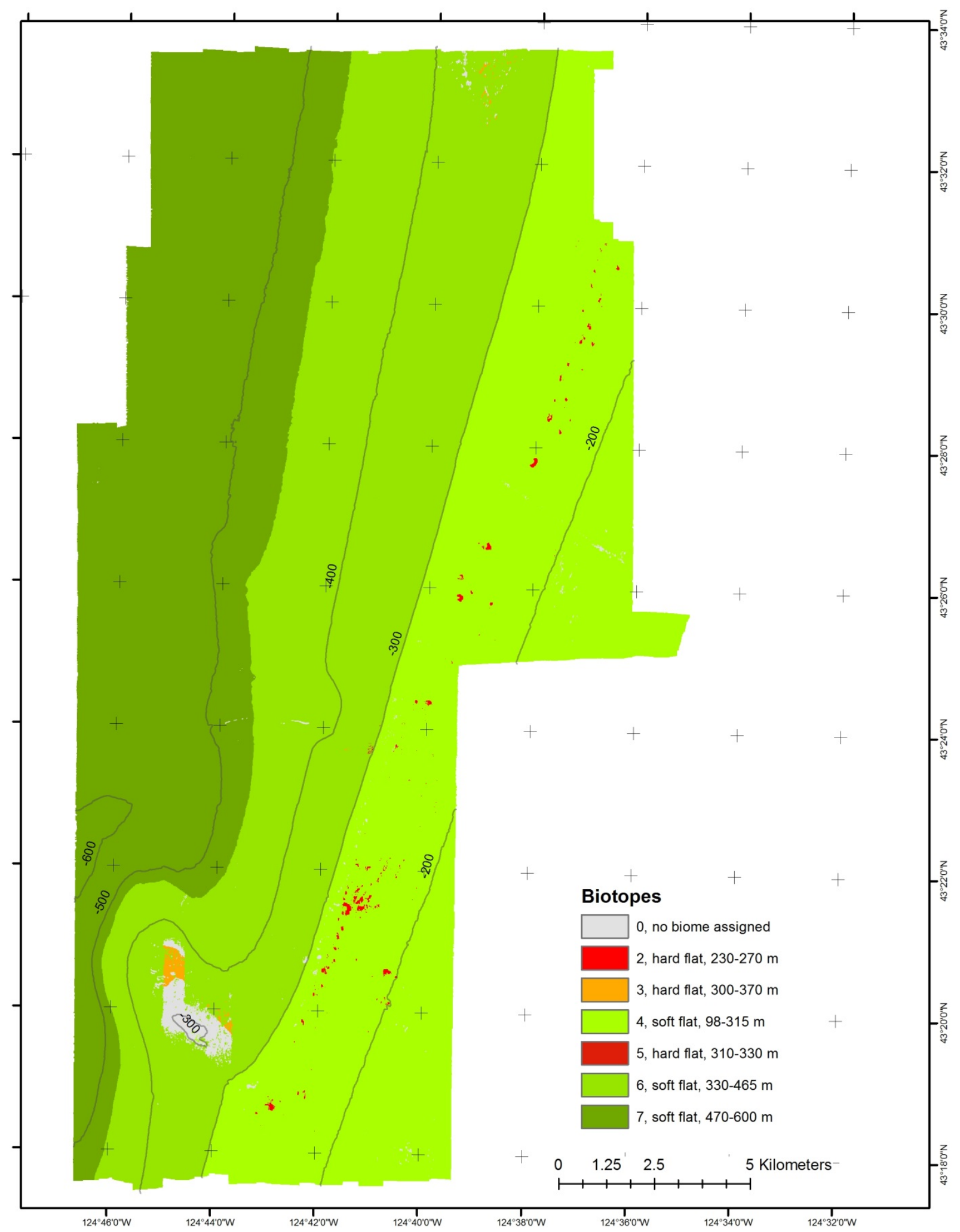

Figure 19. Image of biotope raster. 
Biome 5 areas are restricted to the area of the slump scar in a depth range of 310 to $330 \mathrm{~m}$. The biome is statistically distinguishable from other hard flat substrate areas in the same depth range but not located on the slump scar. There are no permanently attached epifauna in biome 5 . This suggests that the biota there may have been affected by slump activity; possibly epifaunal biota have not recolonized after recent slumping or that the slump scar hard substrate has some physical characteristic that affects the biota.

Table 14. Surface area of each biotope.

\begin{tabular}{lll}
\hline Biome & \multicolumn{1}{c}{ Substrate type and depth } & \multicolumn{1}{c}{ Area $\left(\mathrm{m}^{2}\right)$} \\
\hline 0 & No biome assigned & 199,788 \\
2 & Hard flat substrate at $230-270 \mathrm{~m}$ & 41,784 \\
3 & Hard flat substrate at 300-370m & 42,708 \\
4 & Soft flat substrate at $98-315 \mathrm{~m}$ & $9,138,444$ \\
5 & Hard flat substrate at 310-330m & 756 \\
6 & Soft flat substrate at 330-465m & $10,280,052$ \\
7 & Soft flat substrate at 470-600m & $9,204,492$ \\
\hline
\end{tabular}

Table 14 shows the surface area of each biome within the map area. As was evident in the seafloor character map, soft sediment biomes dominate the map area (99.7 percent). The hard flat substrate in the slump scar represents just 0.003 percent of the surface area of the map area. Hard flat pockmark habitat that supports rockfish cover only 0.15 percent of the map area.

\section{Limitations}

This study presented several limitations that, however, do not affect the scientific robustness of the results, because analyses were carefully chosen and results carefully interpreted with these limitations in mind. First, the video sampling was designed to provide ground truth information for classification of the MBES data into geologic units and investigate interesting geological features, not biological features. However, besides dives 15 and 17 that were added at the very end of the field survey because of some spare time, all the dives were initially planned so that each $100 \mathrm{~m}$ depth bin would be visited at least twice to limit any bathymetrical bias. A better representation of the shallower depth bins (0-100 $\mathrm{m}$ and 100-200 $\mathrm{m}$ ) in the future may improve the biome classification, especially for the soft flat substrate.

A second limitation was the variation in altitude of the video sled above the seafloor owing to the swell at the ocean surface. The seafloor area covered by the video was very inconstant and a fixed width $(1.15 \mathrm{~m})$, which is approximately the transect width at the most common sled altitude above the seafloor, was used to calculate the area covered by each substratum patch and, therefore, the density of each organism. This approximation resulted in densities that are a good proxy of the real densities of sessile and motile organisms in the study area. Only the on-transect (usable) sections of each dive were used for the analyses and no interpolation to the off-transect (unusable) sections were attempted due to the poor reliability of the observations in these off-transect sections.

A third limitation, inherent to all underwater video survey, was the level of taxonomic identifications. It is difficult to reliably identify marine organisms on video footage to the species level due to the low access to diagnostic morphological characters. In this study, only organisms taller than 5 cm were enumerated and identified as morphogroups (for example, white snail, rockfish) or to the genus or species level when possible. The first author reviewed all the videos and identified and enumerated 
all visible organisms to avoid any unevenness of identification among dives. An identification of all specimens to the species level would have required collecting them with bottom-trawl hauls following the tracks of the video sled.

The last limitation combined the drawbacks of the rapid changes in altitude of the sled in relation to the sea bottom owing to surface turbulence combined with the lack of fish identification skills of the video's reviewer. This limitation prevented the reviewer from noticing, identifying, and counting juvenile rockfish, which is essential when assessing critical fish habitats.

\section{Pockmark Habitat}

Biome 2 is restricted to pockmarks on the seafloor with hard flat substrate. The substrate types observed in the video include gravels (up to cobble size) and mud or sand. The shelf sediment surrounding the pockmarks is sandy mud. The coarser sediment within the pockmarks is indicative of active seepage and resultant winnowing of the finer clast sediments. The exposure of large clasts provides a surface for structure-forming crinoids.

In many benthic ecosystems, stalk crinoids and feather stars provide additional habitats for other organisms, such as macrofaunal episymbionts and endosymbionts and parasites (Britayev and Mekhova, 2011; Fishelson, 1974; Hempson and Griffiths, 2009; Schiaparelli and others, 2007) or megafaunal commensal organisms like fish (Colloca and others, 2004; Puniwai, 2002). Some crinoid species are considered indicators of vulnerable marine ecosystems (VMEs) in several areas of the northern Atlantic Ocean, southern Pacific Ocean, and Antarctic Ocean (Anderson and others, 2016; CCAMLR, 2009; Murillo and others, 2011), especially due to their fragility, longevity, and ability to provide habitat for other organisms, among other criteria (http://www.fao.org/in-action/vulnerable-marineecosystems/criteria/en/). They act as structure-forming mega-invertebrates and play a significant role in providing habitat for many valuable fish species, like described for Florometra serratissima in several bank and reef systems dominated by boulders and ridge rocks on the west coast continental shelf of the United States (for example, Bright, 2007; Pirtle, 2005; Tissot and others, 2004, 2006).

Previous studies reported the crinoid, Florometra serratissima, from many substrate types but predominantly from high- to moderate-relief rocky habitats, in dense aggregations on rock ridges that generally declined in less consolidated substrate types (Puniwai, 2002; Strom, 2006; Tissot and others, 2004, 2006). A few studies reported observations of adult and juvenile rockfishes associated with these feather stars (Puniwai, 2002; Tissot and others, 2007), especially in cobble habitats approximately 100$200 \mathrm{~m}$ deep at Heceta Bank, on the Oregon outer continental shelf (Tissot and others, 2007). One of the final biome of this study consisted mainly of crinoids, various fishes (flatfishes, poachers, rockfishes, and thornyheads), and spot prawns in a habitat of cobbles and (or) pebbles scattered over a soft sediment seafloor, 230-270 $\mathrm{m}$ deep. These small rocks seemed to provide sufficient relief for the crinoids to sit on top, which in turn seemed to provide some additional habitat structure to the other taxa previously mentioned, and especially the rockfishes.

For this report additional analysis was performed for data from biome 2 to assess the use of crinoids in pockmarks as a biogenic habitat in an otherwise rather flat environment by three taxa of commercial interest: rockfish, thornyhead, and Pacific spot prawn. The distance of each individual of the three previously mentioned taxa to its closest crinoid was determined, to assess whether each taxon is significantly found in close relation with crinoids, which could be interpreted as a use of the crinoid as habitat, especially for protection. 


\section{Use of Crinoids as Unique Biogenic Habitat for Three Commercially Fished Taxa}

The towed-sled videos for the hard flat substrate patches of final biome 2 (04MC, 04MP, 06MC, $11 \mathrm{MC}$, and 11MP) were reexamined to classify the different individuals of rockfishes, thornyheads, and Pacific spot prawns in three categories depending on their distance to the closest crinoid (fig. 20): (1) "contact" when a fish or prawn was underneath a crinoid's crown of arms or next to it but in contact with at least one arm; (2) "less than body length" when a fish or prawn was seen at a distance smaller than or equal to its body length from the nearest crinoid; and (3) "more than body length" when a fish or prawn was seen at a distance greater than its body length from the nearest crinoid. All rockfish individuals were pooled as "rockfish," even if some had been identified to the species level, because there were counts insufficient to provide statistically valid results for each individual species. Because of large differences in organism counts among sediment patches (for example, 3 rockfishes, 34 thornyheads, 0 spot prawn at 04MC vs. 178 rockfishes, 0 thornyhead, 138 spot prawns at 06MC), all counts for each taxon were pooled among all five patches, so no spatial difference could be assessed between the different sediment patches and dives.

The hypothesis $\mathrm{H} 0$ that individuals of each three taxa were indifferently located away from its nearest crinoid, and its counter-hypothesis H1 that, depending on the species, there was a preference to be either close to the crinoid or away from it, were tested in R (R Development Core Team, 2015) with three chi-squared contingency table tests, treating each taxon as an independent sample. A theoretical effective of 33 percent of each taxon's population was attributed to each distance category as a vector of probability to be tested against.

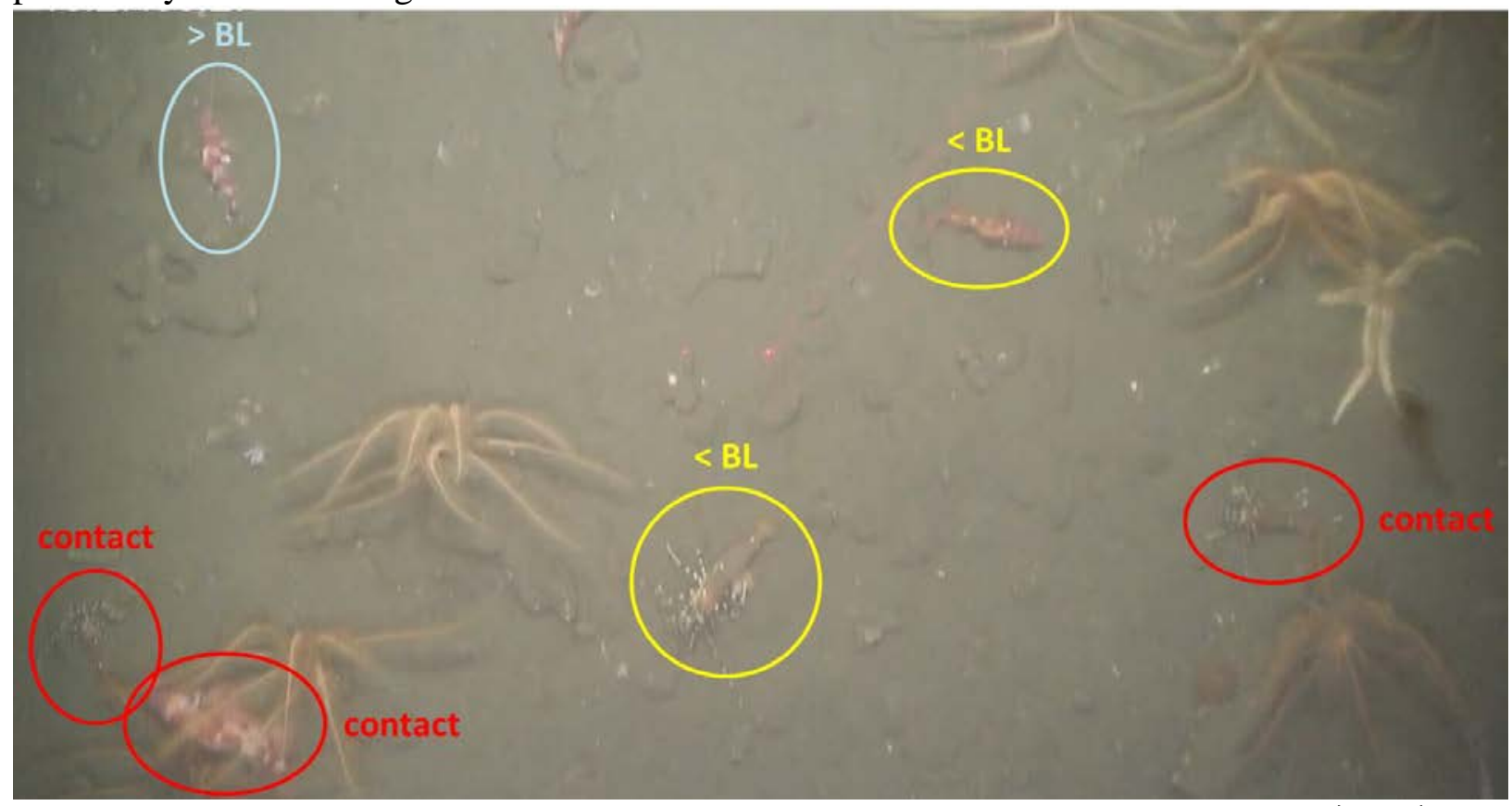

Figure 20. Three distance categories of fishes and prawns from their closest crinoid: contact (in red), less than a body length (<BL, in yellow), and more than a body length ( $>\mathrm{BL}$, in blue).

\section{Crinoid Species Distribution Modeling}

The distribution of the crinoid Florometra serratissima on the Pacific Northwest continental shelf was modeled with the user-friendly maximum entropy modeling software Maxent v. 3.3.3 (Phillips and others, 2006). The model domain extended from lat $39.5^{\circ} \mathrm{N}$. (approximately the latitude of Fort Bragg, CA) to lat $47^{\circ} \mathrm{N}$. (approximately the latitude of Aberdeen, WA), from the coast to roughly 
long $125^{\circ} \mathrm{W}$. (following the $550 \mathrm{~m}$ isobath), and covered soft bottom, rocky reefs, and outcrops (fig. 21). Raster maps of thirteen environmental parameters from three categories (seabed sediments, oceanographic variables, and seafloor relief) were used, of which a detailed description can be found in Hemery and others (2016): sediment mean grain size (MGS), percent of sand, mud, clay and gravel, annual averages of near-bottom temperature (T), salinity (S), eastward (u) and northward (v) horizontal current components, depth, slope, rugosity and probability of rocky outcrops (fig. 21), with a 2 x 2 km resolution.

Despite a total of 2,085 observations of Florometra serratissima recorded during the present video survey, this crinoid species was present at only 5 of the 17 dives. The resolution of the environmental parameter raster maps $(2 \times 2 \mathrm{~km}$, while the average on-transect length of an entire dive was $682 \mathrm{~m}$ ) did not allow counting each single crinoid observation as an occurrence, so one occurrence was used for each of the five dives with crinoids, using their average GPS coordinates as latitude and longitude. Additional crinoid occurrences were gathered from other sources: 16 occurrences from the 2011-2012 ROV transects at Grays Bank, Siltcoos Reef, and Bandon-Arago (Hemery and Henkel, 2016), 45 occurrences from various 1987-1995 Delta dives on many areas of the continental shelf from northern California to southern Washington (Henkel and others, 2014; Hixon and others, 1991; Lissner and others, 1989; Strom, 2006), and 5 occurrences from various 1889-1914 Albatross stations (Clark and Clark, 1967). The locations of these 71 occurrences are shown on figure 21.

To counter-balance any sampling bias, a sampling bias grid was created in $\mathrm{R}$ using a twodimensional kernel density estimate, based on the coordinates of the 71 occurrences. Ten replicated bootstrap runs of MaxEnt were computed, using all available background points $(10,459)$, the sampling bias grid, a 3:1 ratio between training and test datasets, and a jackknife procedure to calculate the percent contribution of the environmental variables to the model. All other settings were used with their default value, especially features (auto, which combines linear, quadratic, product, hinge, threshold, and categorical features, with interaction terms) and output format (logistic) settings. The performance of the model was evaluated by using the area under the receiver operating characteristic curve (AUC). 

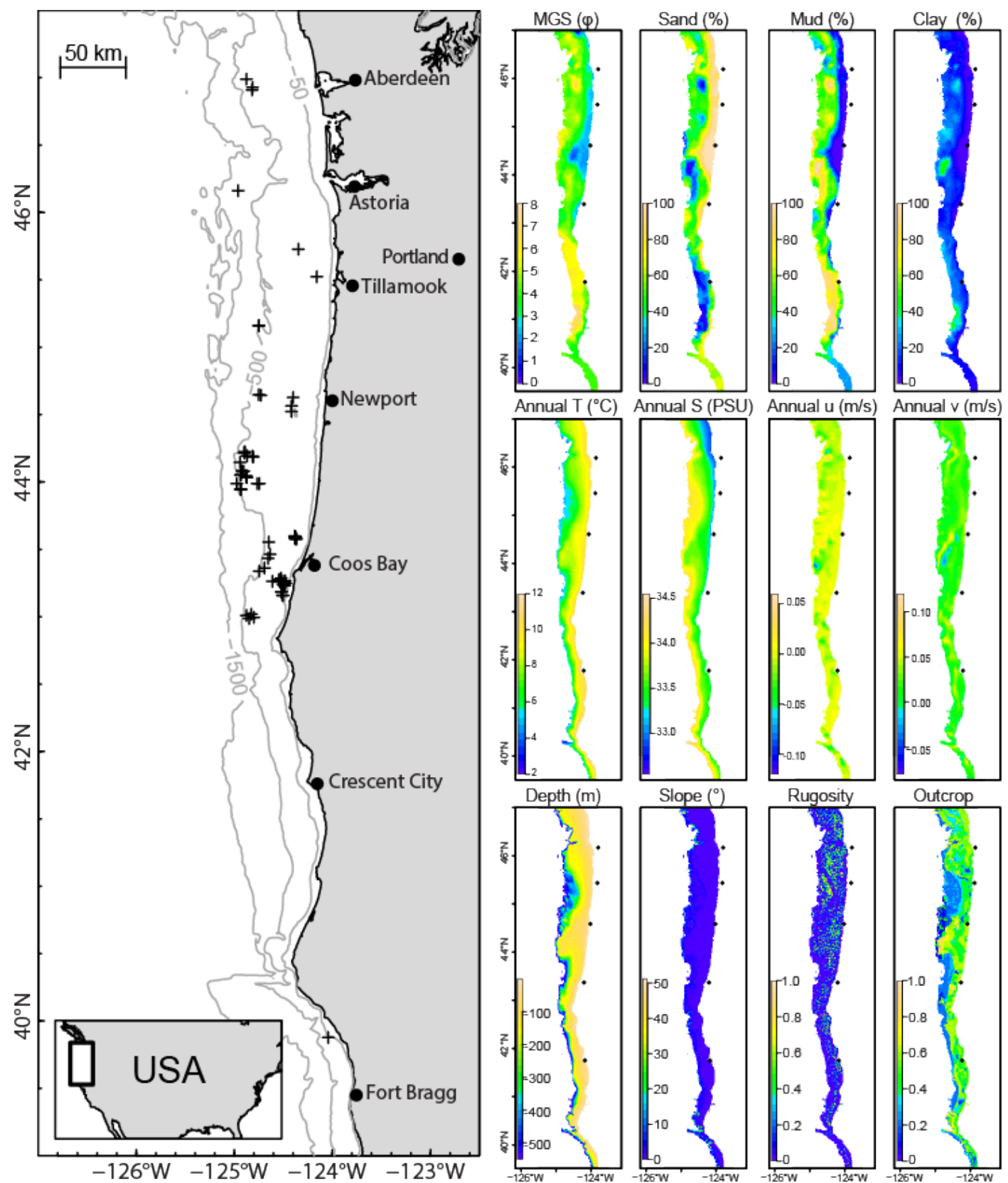

Figure 21. Distribution of the crinoid Florometra serratissima occurrences (+, map) and of the 13 environmental parameters (graphs; modified from Hemery and others, 2016) used in this study.

\section{Pockmark Habitat Significance}

The distance from its nearest crinoid was assessed for a total of 193 rockfishes (6 at dive 04, 180 at dive 06, and 7 at dive 11), 74 thornyheads (51 at dive 04 and 23 at dive 11), and 176 Pacific spot prawns (1 at dive 04, 138 at dive 06, and 37 at dive 11) (table 15). A great majority of the rockfishes (74.6 percent) were found in contact with crinoids while the opposite was found for the thornyheads with most of the fishes (85.1 percent) away from crinoids by more than their body length (table 15; fig. 22). The chi-squared contingency table tests returned significant (p-values <2.2e-16) for these two taxa allowing the rejection of $\mathrm{H} 0$, meaning that neither rockfishes nor thornyheads were distributed randomly around crinoids but rockfishes tended to be significantly close to the crinoids whereas thornyheads were 
significantly found away from the crinoids. About a third of the Pacific spot prawns were found either in contact with crinoids, at a body length from them, or at greater distance than a body length away from its nearest crinoid (table 15; fig. 22). The chi-squared contingency table test on this taxon returned a pvalue of 0.1903, not allowing the rejection of H0, meaning that the Pacific spot prawns were distributed randomly around crinoids.

Table 15. Counts of rockfishes, thornyheads, and Pacific spot prawns in contact with crinoids (Contact), at a body length or less away from its nearest crinoid $(<\mathrm{BL})$ and at more than a body length away from its nearest crinoid $(>$ $\mathrm{BL}$ ) within hard flat substrate patches of dives 04,06 , and 11.

\begin{tabular}{lllll}
\hline & Contact & $<\mathrm{BL}$ & $>\mathrm{BL}$ & Total \\
\hline Rockfish & 144 & 33 & 16 & 193 \\
Thornyhead & 6 & 5 & 63 & 74 \\
Pacific spot prawn & 54 & 70 & 52 & 176 \\
\hline
\end{tabular}

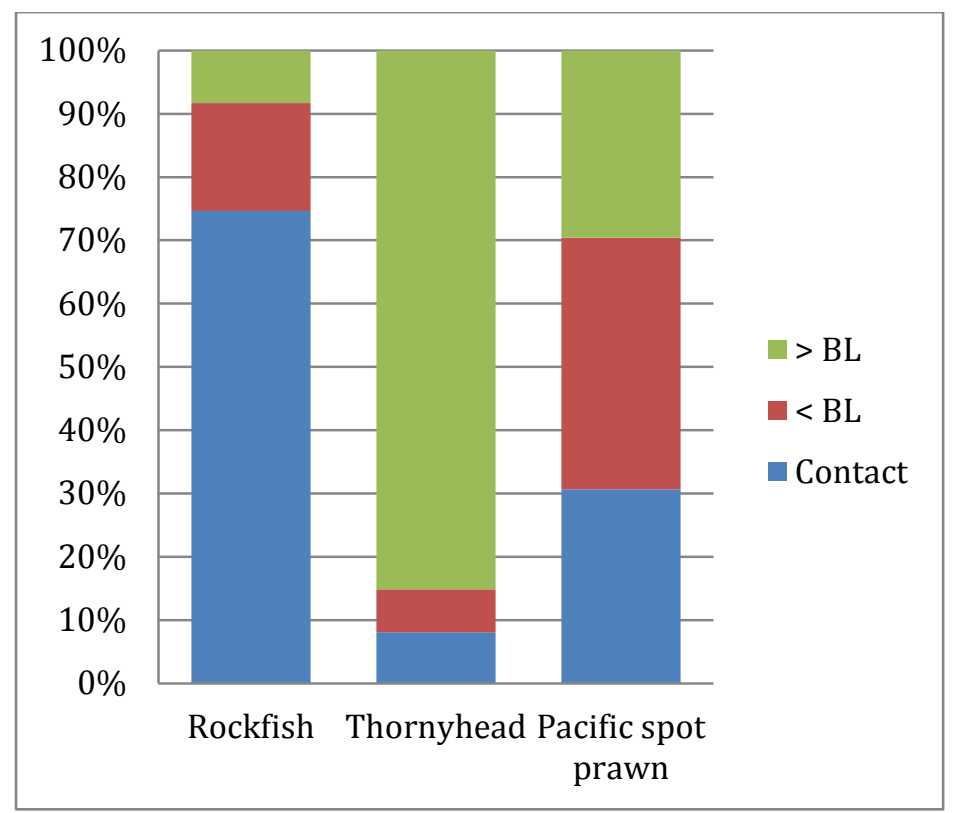

Figure 22. Proportions of rockfishes, thornyheads, and Pacific spot prawns in contact with crinoids (Contact), at a body length or less away from its nearest crinoid $(<\mathrm{BL})$ and at more than a body length away from its nearest crinoid (> BL) within hard flat substrate patches of dives 04,06 , and 11.

Averaged on the 10 bootstrap runs, the training AUC value was 0.937 while the test AUC value was 0.837 , which indicates a strong fit of the data to the model. The modeled distribution of Florometra serratissima was rather limited (fig. 23), with 54 percent of the pixels of the map having a probability of presence of the crinoid of 0.5 or less (fig. 23, green to blue), 20 percent with a probability greater than 0.75 (fig. 23, yellow to orange), and only 4 percent with a probability greater than 0.9 (fig. 23, pale orange). These highest-probability pixels were located on the Mendocino Ridge only, in northern California (north of Fort Bragg). Nonetheless, the tops of the Grays Canyon and Astoria Canyon walls, as well as the area of numerous banks and rocky outcrops (for example, Stonewall, Heceta, Coquille, Bandon-Arago), showed a probability of presence of the crinoid higher than 0.65 . However, this species distribution modeling did not return a probability of presence of Florometra serratissima higher than 0.35 in the present study area off Coos Bay. The probability of rocky outcrop was by far the 
environmental parameter contributing the most to the model (44.5 percent; table 16), followed by slope (11.3 percent) and depth (10.9 percent). Oceanographic variables contributed for less than 5 percent each.

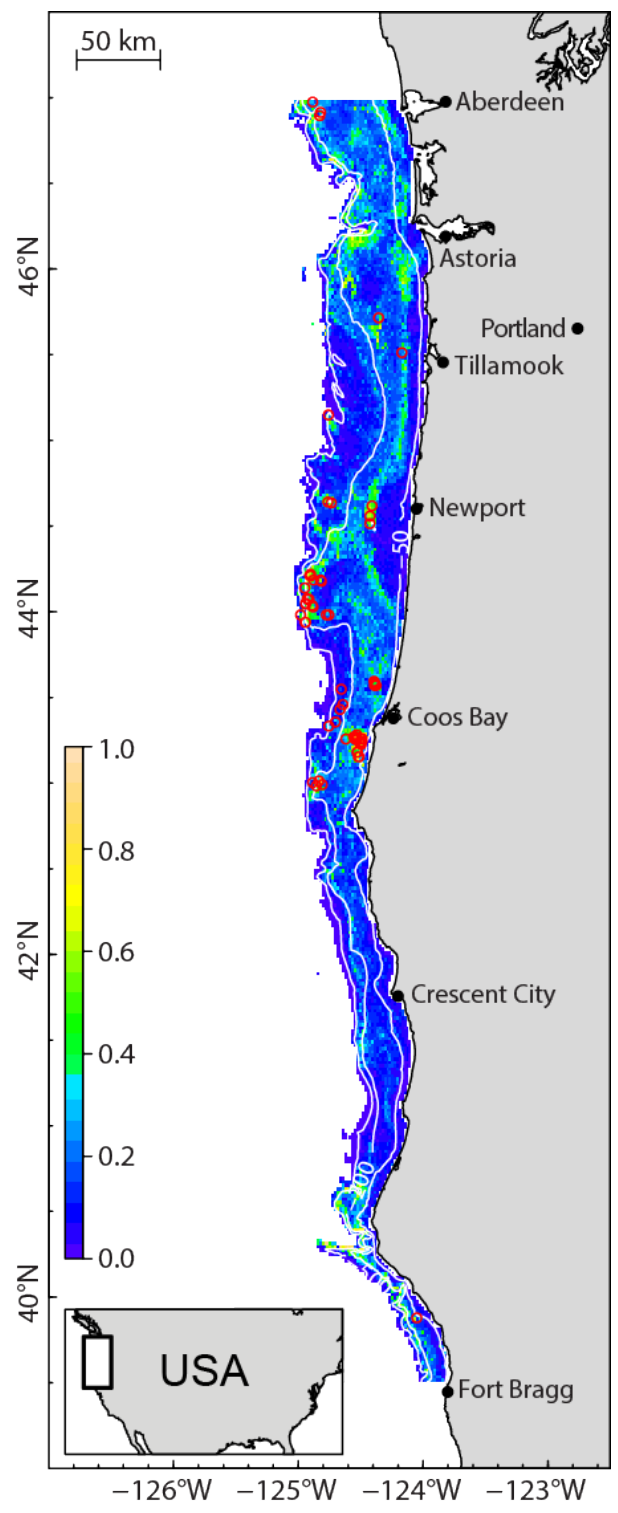

Figure 23. Probability of distribution of the crinoid Florometra serratissima as modeled by Maxent. Isobaths ( 50 , 200, and $500 \mathrm{~m}$ deep) are white; crinoid occurrences are in red circles.

The spatial resolution of the environmental parameters used in the species distribution modeling was too coarse $(2 \times 2 \mathrm{~km})$ to show geological features of relatively small size, like the pockmarks highlighted during the dives 04, 06, and 11. In addition, none of the three most important variables for the distribution of Florometra serratissima (outcrop, depth, and slope) showed values along the 230$270 \mathrm{~m}$ isobaths in the study area that were different from the surroundings, potentially explaining why the pockmarks were missed as a location of high probability of presence for this crinoids species. The spatial resolution was here constrained by the resolution of the oceanographic parameters, whereas the initial spatial resolution, before resampling, of the seabed sediments and seafloor relief parameters was either 8 x 8 m or 200 x 200 m (Goldfinger and others, 2014). Oceanographic parameters (temperature, 
salinity, and current) were here included based on the results of the single previous study that looked at ecological niche and habitat modeling for another species of crinoids (Hemery and others, 2011), in which temperature, salinity, and current magnitude were the most important parameters explaining the distribution of their species of interest. Feather stars are rheophilic suspension feeders that select low to moderate current velocity (0-15 cm/s; Hemery and others, 2011; Meyer, 1997). However, the four oceanographic parameters contributed so little to the present model for F. serratissima that a new modeling analysis at higher resolution, without these four variables, could be attempted to refine the potential distribution of $F$. serratissima.

Table 16. Percent contribution of each thirteen environmental variable to the Maxent model.

[v (northward horizontal current component); u (eastward horizontal current component); T (near bottom temperature) ; S (near bottom salinity)]

\begin{tabular}{ll}
\hline \multicolumn{1}{c}{ Variable } & Percent contribution \\
\hline Outcrop & 44.5 \\
Slope & 11.3 \\
Depth & 10.9 \\
Rugosity & 8.7 \\
Clay & 8.5 \\
Mud & 5.0 \\
Annual v & 3.3 \\
Sand & 2.3 \\
Annual T & 1.9 \\
Annual u & 1.9 \\
Mean Grain Size & 1.1 \\
Gravel & 0.4 \\
Annual S & 0.1 \\
\hline
\end{tabular}

Despite this limitation, crinoids were modeled to be present at canyon heads, ridges, and banks, even where no occurrences were available for the modeling. These habitats are the type of habitats usually suitable to many valuable rockfish species (Hixon and others, 1991; Stein and others, 1992; Tissot and others, 2007, 2008; Yoklavich and others, 2000). However, several rockfish species have shown limited dispersal abilities and genetic patterns of isolation-by-distance, linked to the patchiness of their rocky habitats and the presence of more-or-less permeable oceanographic barriers in several areas of the California current system (Johansson and others, 2008; Lotterhos and others, 2014; Miller and Shanks, 2004; and references herein). Pockets of mixed-sediment habitats where most of the pebbles and cobbles are capped with crinoids, like the alignment of pockmarks observed in the present study along the 230-270 m isobaths 15 miles west of Coos Bay, can add some habitat structure and complexity in otherwise rather flat soft-sediment areas of the continental shelf. Because of the statistically significant utilization of crinoids as additional habitat by rockfishes, this specific habitat could work as a link between larger rocky habitats and their rockfish populations. If these pockmarks were present along a large section of the Oregon outer continental shelf, they could connect, from south to north, Coquille, Heceta, and Daisy banks, which are all Essential Fish Habitats closed to bottom trawling (NMFS, 2013). On the other hand, thornyheads are known to live indifferently on soft- or mixed-sediment habitats (Butler and others, 2012) and seem to avoid the additional structure provided by the crinoids, whereas the Pacific spot prawns seem to be indifferent to the presence of feather stars in their environment. There are thus fewer chances for the distribution of thornyheads and Pacific spot 
prawns to be associated to the distribution of the crinoid, Florometra serratissima, on the west coast continental shelf of the United States than for rockfishes.

The pockmarks hosting this crinoid-rockfish biome fulfill the vulnerable marine ecosystem (VME) criterion \#1 of uniqueness (http://www.fao.org/in-action/vulnerable-marineecosystems/criteria/en/) in the way that this association of small rocks, crinoids, and rockfishes (among other organisms) is distinctive in an otherwise rather flat and muddy environment that does not provide any shelter for rockfish species on a very wide section of the Oregon continental shelf. This habitat has a strong functional significance (VME criterion \#2) because the crinoids provide additional structure for the fishes to hide under and the succession of pockmarks along the 230-270 m isobaths may work as links between populations of rockfishes on rocky banks. This ecosystem can be considered fragile (VME criterion \#3) because there is no big relief (boulders, ridges) to protect these pockmarks from bottom-contact fishing activities, as evidenced by the crab pot seen on dive 04, the numerous ropes tangled among the cobbles on dive 06, and the fishing line on dive 11 . In addition, crinoids are very fragile organisms that can be severely damaged by any bottom-contact gear and, if the damage is too severe, their natural capacity to regenerate could be seriously altered. This habitat also fulfills the criterion \#4 (life-history traits of component species that make recovery difficult) in the sense that most of the rockfish species have a slow growth rate and a late age of maturity and are long-lived (Lea and others, 1999). Although nothing is known about Florometra serratissima's life-history traits, crinoids in general are thought to be long-lived (Messing and others, 2007; Roux, 1976). VME's fifth criterion (structural complexity) is also met, as explained above for criteria \#1 and \#2, which suggests that crinoids may provide to the habitat some additional structure that the here-lacking corals and sponges add to other deep-sea ecosystems.

However, only three of these pockmarks were visited during the 2014 video-sled survey (dive 04, 06, and 11) and the abundance of crinoids and rockfishes were very different among sites. More than half of the rockfishes (180 out of 306) recorded during the current study were observed in the pockmark at dive 06 (06MC), along with a third of the overall crinoid count, whereas pockmarks at dives 04 and 11 showed very few, if any, rockfishes, and fewer crinoids. The backscatter images of the surveyed 95 $\mathrm{km}^{2}$ of the seafloor off Coos Bay showed at least a dozen similar pockmarks. It would be interesting to characterize them all and make sure that this entire biome is not restricted to just the three sites visited during the reported survey, especially 06MC that seems to be unique. A specific study, with dedicated sampling surveys located at a maximum of pockmarks along this narrow depth range, would help understand the role of this specific habitat in connecting populations of various valuable species along the Oregon outer continental shelf. At least part of the alignment of pockmarks along the 230-270 m isobaths 15 miles west of Coos Bay fulfills all the criteria of a vulnerable marine environment. This should be acknowledged in case of any development of activities requiring contact with the seafloor, whatever these activities are (for example, bottom-contact fishing, installation of marine renewable energy devices, deployment of underwater cables), to lead to as little damage as possible to these pockets of highly valuable habitat used by several species with commercial interest and specific protection needs.

\section{Acknowledgments}

This publication was funded by the Bureau of Ocean Energy Management under Intra-agency Agreement M13PG00037. We thank Brian Tissot (Humboldt State University) and Tom Lorenson (USGS) for their critical reviews that greatly improved this report. Pete Dartnell, David Finlayson, Gerry Hatcher, Jackson Currie, Peter Dal Ferro, Robert Wyland, and Jenny White contributed their 
technical expertise as participants in the data acquisition

(http://compass.er.usgs.gov/fan_info.php?fan=2014-607-FA).

\section{References Cited}

Anderson, O.F., Guinotte, J.M., Rowden, A.A., Clark, M.R., Mormede, S., Davies, A.J., Bowden, D.A., 2016, Field validation of habitat suitability models for vulnerable marine ecosystems in the South Pacific Ocean: Implications for the use of broad-scale models in fisheries management: Ocean \& Coastal Management v. 120, p. 110-126.

Anderson, T.J., Cochrane, G.R., Roberts, D.A., Chezar, H., and Hatcher, G., 2007, A rapid method to characterize seabed habitats and associated macro-organisms, in Todd, B.J., and Greene, H.G., eds., Mapping the seafloor for habitat characterization: Geological Association of Canada Special Paper 47, p. 71-79.

Bright, J.L., 2007, Abundance and distribution of structure-forming invertebrates and their association with fishes at the Channel Islands "footprint" off the southern coast of California: Vancouver, WA, Washington State University, M.S. thesis, 76 p.

Britayev, T.A., and Mekhova E.S., 2011, Assessment of hidden diversity of crinoids and their symbionts in the Bay of Nhatrang, Vietnam: Organisms Diversity \& Evolution, v.11, p. 275-285. Butler, J.L., Love, M.S., and Laidig, T.E., 2012, A guide to the rockfishes, thornyheads, and scorpionfishes of the Northeast Pacific: University of California Press, 185 p.

CCAMLR, 2009, CCAMLR VME Taxa Classification Guide 2009: Hobart, Tasmania, Australia, Commission for the Conservation of Antarctic Marine Living Resources, 4 p.

Clark, A.H., and Clark, A.M., 1967, A monograph of the existing crinoids, Volume 1; the comatulids, part 5, Suborders Oligophreata (concluded) and Macrophreata: Bulletin of the United States National Museum v. 82, p. 1-795.

Clarke, K.R., and Gorley, R.N., 2006, PRIMER v6: User Manual/Tutorial. PRIMER-E, Plymouth, accessed February 24, 2017, at https://www.researchgate.net/publication/285668711_PRIMER_v6_user_manualtutorial_PRIMERE_Plymouth.

Clarke, S.H., Field, M.E., and Hirozawa, C.A, 1985, Reconnaissance geology and geologic hazards of the offshore Coos Bay Basin, Oregon: Geological Survey Bulletin 1645, 41 p.

Cochrane, G.R., 2008, Video-supervised classification of sonar data for mapping seafloor habitat, in Reynolds, J.R., and Greene, H.G., eds., Marine habitat mapping technology for Alaska: Fairbanks, University of Alaska, Alaska Sea Grant College Program, p. 185-194, accessed February 24, 2017, at https://walrus.wr.usgs.gov/mapping/csmp/CochraneNPRB174.pdf.

Cochrane, G.R., 2017, Data release for Oregon OCS Seafloor Mapping: Selected Lease Blocks Relevant to renewable Energy: U.S. Geological Survey Data Release, accessed February 24, 2017, at http://dx.doi.org/10.5066/F7000069.

Cochrane, G.R., Dartnell, P., Hemery, L.G., and Hatcher, G., 2015, Data release for USGS field activity 2014-607-FA, Oregon OCS seafloor mapping; selected lease blocks relevant to renewable energy: U.S. Geological Survey Data Release, accessed February 24, 2017, at http://dx.doi.org/10.5066/F7V40S8V.

Colloca, F., Carpentieri, P., Balestri, E., and Ardizzone, G.D., 2004, A critical habitat for Mediterranean fish resources; shelf-break areas with Leptometra phalangium (Echinodermata: Crinoidea): Marine Biology, v. 145, p. 1129-1142.

Fishelson, L., 1974, Ecology of the northern Red Sea crinoids and their epi- and endozoic fauna: Marine Biology, v. 26, p. 183-192. 
Froese, R., and Pauly, D., 2015, FishBase: accessed February 24, 2017, at www.fishbase.org.

Goldfinger, C., Henkel, S.K., Romsos, C., Havron, A., and Black, A., 2014, Benthic habitat characterization offshore the Pacific Northwest, Volume 1; evaluation of continental shelf geology: U.S. Department of the Interior, Bureau of Ocean Energy Management, Pacific OCS Region, OCS Study BOEM 2014-662, 161 p.

Goldfinger, C., Kulm, L.D., Yeats, R.S., McNeill, L., and Hummon, C. 1997, Oblique strike-slip faulting of the central Cascadia submarine forearc: Journal of Geophysical Research, v. 102, p. 82178243.

Hannah, R.W., Jones, S.A., Kupillas, S., and Miller, W., 2013, A comparison of 2007 and 2013 macroinvertebrate surveys of mud habitats at Nehalem Bank, Oregon; changes in areas with continued trawling and those closed to trawling in 2006: Oregon Department of Fish and Wildlife Information Reports 2014-2003, p. 1-30.

Hannah, R.W., Jones, S.A., Miller, W., and Knight, J.S., 2010, Effects of trawling for ocean shrimp (Pandalus jordani) on macroinvertebrate abundance and diversity at four sites near Nehalem Bank, Oregon: Fishery Bulletin, v. 108, p. 30-38.

Hemery, L.G., Galton-Fenzi, B., Améziane, N., Riddle, M.J., Rintoul, S.R., Beaman, R.J., Post, A.L., and Eléaume, M., 2011, Predicting habitat preferences for Anthometrina adriani (Echinodermata) on the East Antarctic continental shelf: Marine Ecology Progress Series, v. 441, p. 105-116.

Hemery, L.G., and Henkel, S.K., 2015, Patterns of benthic mega-invertebrate habitat associations in the Pacific Northwest continental shelf waters: Biodiversity and Conservation, v. 24, p. 1691-1710.

Hemery, L.G., and Henkel, S.K., 2016, Patterns of benthic mega-invertebrate habitat associations in the Pacific Northwest continental shelf waters; a reassessment: Biodiversity and Conservation, v. 25, p. 1761-1772.

Hemery, L.G., Marion, S.R., Romsos, C.G., Kurapov, A.L., and Henkel, S.K., 2016, Ecological niche and species distribution modelling of sea stars along the Pacific Northwest continental shelf: Diversity and Distributions, v. 22, no. 12, p.1314-1327, accessed February 24, 2017, at http://onlinelibrary.wiley.com/doi/10.1111/ddi.12490/full.

Hempson. T.N., and Griffiths, C.L., 2009, Symbionts of comatulid crinoids in False Bay, South Africa: African Zoology, v. 43, no. 2, p. 237-244.

Henkel, S.K., Goldfinger, C., Romsos, C., Hemery, L.G., Havron, A., and Politano, K., 2014, Benthic habitat characterization offshore the Pacific Northwest, Volume 2; evaluation of continental shelf benthic communities: U.S. Department of the Interior, Bureau of Ocean Energy Management, Pacific OCS Region, OCS Study BOEM 2014-662, 218 p.

Hixon, M.A., and Tissot, B.N., 2007, Comparison of trawled vs. untrawled mud seafloor assemblages of fishes and macroinvertebrates at Coquille Bank, Oregon: Journal of Experimental Marine Biology and Ecology, v. 344, p. 23-34.

Hixon, M.A., Tissot, B.N., and Pearcy, W.G., 1991, Fish assemblages of rocky banks of the Pacific Northwest: A final report by the Department of Zoology and College of Oceanography of Oregon State University for the U.S. Department of the Interior, Minerals Management Service, Pacific OCS Office, $427 \mathrm{p}$.

Hovland, M., Gardner, J.V., and Judd, A.G., 2002, The significance of pockmarks to understanding fluid flow processes and geohazards: Geofluids, v. 2, p. 127-136.

Johansson, M.L., Banks, M.A., Glunt, K.D., Hassel-Finnegan, H.M., and Buonaccorsi, V.P., 2008, Influence of habitat discontinuity, geographical distance, and oceanography on fine-scale population genetic structure of copper rockfish (Sebastes caurinus): Molecular Ecology, v. 17, p. 3051-3061. 
Kulm, L.D., and Fowler, G.A., 1974, Oregon continental margin structure and stratigraphy; A test of the imbricate thrust model, in Burk, C.A., and Drake, C.L., The Geology of Continental Margins: Springer-Verlag, p. 261-283.

Kulm, L.D., Suess, E., Moore, J.C., Carson, B., Lewis, B.T., Ritger, S.D., Kadko, D.C., Thornburg, T.M., Embley, R.W., Rugh, W.D., Massoth, G.J., Langseth, M.G., Cochrane, G.R., and Scamman, R.L., 1986, Oregon subduction zone; venting, fauna, and carbonates: Science, v. 231, p. 561-566.

Lea, R.N., McAllister, R.D., and Ventresca, D.A., 1999, Biological aspects of the nearshore rockfishes of the genus Sebastes from central California: California Department of Fish and Game, Fish Bulletin, v. 177, p. 1-109.

Lissner, A., Barnett, A., Johnson, T., Kanter, R., and Smith, R., 1989, Benthic reconnaissance of central and northern California OCS areas: A final report by Science Applications International Corporation and MEC Analytical Systems Inc. for the U.S. Department of the Interior, Minerals Management Service, Pacific OCS Office, 330 p.

Lotterhos, K.E., Dick, S.J., and Haggarty, D.R., 2014, Evaluation of rockfish conservation area networks in the United States and Canada relative to the dispersal distance for black rockfish (Sebastes melanops): Evolutionary Applications, v. 7, p. 238-259.

Madden, C.J., Goodin, K.L., Allee, R., Finkbeiner, M., and Bamford, D.E., 2008, Draft Coastal and Marine Ecological Classification Standard: National Oceanic and Atmospheric Administration (NOAA) and NatureServe, v. III, 77 p.

Messing, C.G., David, J., Roux, M., Améziane, N., and Baumiller, T.K., 2007, In situ stalk growth rates in tropical western Atlantic sea lilies (Echinodermata: Crinoidea): Journal of Experimental Marine Biology and Ecology, v. 353, p. 211-220.

Meyer, D.L., 1997, Reef crinoids as current meters; feeding responses to variable flow: Proceedings of the 8th International Coral Reef Symposium, Panama City, v. 2, p. 1127-1130.

Miller, J.A., and Shanks, A.L., 2004, Evidence for limited larval dispersal in black rockfish (Sebastes melanops); implications for population structure and marine-reserve design: Canadian Journal of Fisheries and Aquatic Sciences, v. 61, p. 1723-1735.

Murillo, F.J., Kenchington, E., Sacau, M., Piper, D.J.W., Wareham, V., Muñoz, A., 2011, New VME indicator species (excluding corals and sponges) and some potential VME elements of the NAFO Regulatory Area. Report of the NAFO SC Working Group on the ecosystem approach to fisheries management, Serial No. N6003, 20 p.

NMFS, 2013, Groundfish Essential Fish Habitat synthesis; a report to the Pacific Fishery Management Council: Seattle, WA, National Oceanic and Atmospheric Administration (NOAA), National Marine Fisheries Service (NMFS), Northwest Fisheries Science Center, 107 p.

Phillips, S.J., Anderson, R.P., and Schapire, R.E., 2006, Maximum entropy modeling of species geographic distributions: Ecological Modeling, v. 190, nos. 3-4, p. 231-259.

Pirtle, J.L., 2005, Habitat-based assessment of structure-forming megafaunal invertebrates and fishes on Cordell Bank, California: Vancouver, WA, Washington State University, M.S. thesis, 74 p.

Puniwai, N.P.F., 2002, Spatial and temporal distribution of the crinoid Florometra serratissima on the Oregon continental shelf: Vancouver, WA, Washington State University, M.S. thesis.

R Development Core Team, 2015, R; a language and environment for statistical computing: R Foundation for Statistical Computing, Vienna, accessed February 24, 2017, at http://www.Rproject.org.

Riedl, R., 1971, Water movement; animals, in Kinne, O. (ed), Marine ecology; a comprehensive, integrated treatise on life in oceans and coastal waters: London, Inter-Research Science Center, p. 1123-1156. 
Roux, M., 1976, Aspects de la variabilité et de la croissance au sein d'une population de la pentacrine actuelle; Annacrinus wyvillethomsoni Jeffreys (Crinoidea): Thalassia Yogoslavica, v. 12, p. 307-320.

Schiaparelli, S., Ghirardo, C., Bohn, J., Chiantore, M., Albertelli, G., and Cattaneo-Vietti, R., 2007, Antarctic associations; the parasitic relationship between the gastropod Bathycrinicola tumidula (Thiele, 1912) (Ptenoglossa: Eulimidae) and the comatulid Notocrinus virilis (Mortensen, 1917) (Crinoidea: Notocrinidae) in the Ross Sea: Polar Biology, v. 30, p. 1545-1555.

Snavely, P.D., 1987, Tertiary geologic framework, neotectonics, and petroleum potential of the OregonWashington continental margin, in Vedder, J.G., ed., Geology and resource potential of the western North America and adjacent ocean basins-Beaufort Sea to Baja California: Circum-Pacific Council for Energy and Mineral Resources, Earth Science Series, v. 6, p. 305-335.

Stein, D.L., Tissot, B.N., Hixon, M.A., and Barss, W., 1992, Fish habitat associations on a deep reef at the edge of the Oregon continental shelf: Fishery Bulletin, v. 90, p. 540-551.

Strom, N., 2006, Structure-forming benthic invertebrates; habitat distributions on the continental margins of Oregon and Washington: Corvallis, OR, Oregon State University, M.S. thesis, 111 p.

Tissot, B.N., 2008, Video analysis, experimental design, and database management of submersiblebased habitat studies, in Reynolds, J.R., and Greene, H.G., eds., Marine habitat mapping technology for Alaska: University of Alaska Fairbanks, Alaska Sea Grant College Program, p. 157-167.

Tissot, B.N., Hixon, M.A., and Stein, D.L. 2007, Habitat-based submersible assessment of macroinvertebrate and groundfish assemblages at Heceta Bank, Oregon, from 1988 to 1990: Journal of Experimental Marine Biology and Ecology, v. 352, p. 50-64.

Tissot, B.N., Wakefield, W.W., Hixon, M.A., and Clemons, J.E.R., 2008, Twenty years of fish-habitat studies on Heceta Bank, Oregon, in Reynolds, J.R., and Greene, H.G., eds., Marine habitat mapping technology for Alaska: University of Alaska Fairbanks, Alaska Sea Grant College Program, p. 203217.

Tissot, B.N., Wakefield, W.W., Puniwai, N.P.F., Pirtle, J., York, K., and Clemons J.E.R., 2004, Abundance and distribution of structure-forming megafaunal invertebrates, including cold-water corals, on Heceta Bank, Oregon, 2000-2002: National Oceanic and Atmospheric Administration (NOAA) Technical Report, 48 p.

Tissot, B.N., Yoklavich, M.M., Love, M.S., York, K., and Amend, M., 2006, Benthic invertebrates that form habitat on deep banks off southern California, with special reference to deep sea coral: Fishery Bulletin, v. 104, p. 167-181.

Triezenberg, P.J., Hart, P.E., and Childs, J.R., 2016, National Archive of Marine Seismic Surveys (NAMSS); A USGS data website of marine seismic reflection data within the U.S. Exclusive Economic Zone (EEZ): U.S. Geological Survey Data Release, doi: 10.5066/F7930R7P, at https://walrus.wr.usgs.gov/NAMSS/.

Wentworth, C.K., 1922, A scale of grade and class terms for clastic sediments: Journal of Geology, v. 30, p. 377-392.

Witter, R.C., Kelsey, H.M., and Hemphill-Haley, E., 2003, Great Cascadia earthquakes and tsunamis of the past 6,700 years, Coquille River estuary, southern coastal Oregon: Geologicl Society of America Bulletin, v. 115, no. 10, p. 1289-1306.

Wright, D.J., Pendleton, M., Boulware, J., Walbridge, S., Gerlt, B., Eslinger, D., Sampson, D., and Huntley, E. 2012. ArcGISBenthic Terrain Modeler (BTM), v. 3.0, Environmental Systems Research Institute, NOAA Coastal Services Center, Massachusetts Office of Coastal Zone Management, accessed February 24, 2017, at http://www.arcgis.com/home/item.html?id=b0d0be66fd33440d97e8c83d220e7926 
Yoklavich, M.M., Greene, H.G., Cailliet, G.M., Sullivan, D.E., Lea, R.M., and Love, M.S., 2000, Habitat associations of deep-water rockfishes in a submarine canyon; an example of a natural refuge: Fishery Bulletin, v. 98, p. 625-641. 
ISSN 2331-1258 (online)

https://doi.org/10.3133/ofr20171045 